\title{
QUANTITATIVE ELECTROPHORETIC STUDY \\ OF RABBIT MUSCLE PROTEINS SOLUBLE IN DILUTE SALT SOLUTIONS*
}

\author{
by \\ M. W. BOSCH \\ Laboratory of Physiological Chemistry, University, Utrecht (Netherlands)
}

\section{INTRODUCTION}

The muscle proteins can be divided into three groups ${ }^{1}$ :

I. Corpuscular proteins soluble in dilute salt solutions (about $0.15 M$ ) at neutral or weakly alkaline $\mathrm{p}_{\mathrm{H}}$ (myogen, globulin-X). These are the proteins, existing in the free state or only bound by very weak forces to the proteins responsible for the rigidity of the muscle.

2. Fibrous proteins, consisting of interlinked peptide chains (myosin, actomyosin). They can only be dissolved by rupture of part of these links by treatment of the muscle with salt solutions of much higher concentration, e.g. $0.5 \mathrm{M} \mathrm{KCl}$ solution of $\mathrm{p}_{\mathrm{H}} 7.5$ to 9.5.

3. Proteins, insoluble even at these salt concentrations at $\mathrm{pH}_{\mathrm{H}} 6.0$ to I0.0 (stroma proteins).

In this paper electrophoresis experiments of the proteins soluble in dilute salt solutions, mentioned sub (I), are described, and the quantitative aspect of the problem is stressed in particular. They are part of investigations aiming at the characterization of muscle in health and disease, started in this laboratory.

These proteins have also been investigated with the electrophoresis technique by JACOB ${ }^{2}$.

\section{EXPERIMENTAL PART}

\section{METHODS}

\section{Extraction}

I. Striated muscle. The rabbit was injected intraperitoneally with $0.060 \mathrm{~g}$ penthotal-sodium (Abbott) per $\mathrm{kg}$ body weight. In about three minutes it was in deep narcosis. The abdomen was opened and the animal bled by the aorta. After evisceration and removal of the skin from the hind legs the carcass was placed in a refrigerated room $\left(2^{\circ} \mathrm{C}\right)$. All further manipulations for extraction were carried out in this room. After one hour - by far too short a time for the development of rigor mortis $^{3}$, but sufficient for causing a very strong decrease of the excitability of the muscles-the hind legs were cut off and the muscles most suitable for investigation were isolated.

The M. vastus lateralis was chosen as a representative of the white muscles, the M. glutaeus

" This work forms part of the investigations on the chemistry of muscle diseases by H. G. K. Whstenbrink and collaborators, supported by a grant from the Netherlands Organisation for Pure Research (Z.W.O.). Requests for reprints should be addressed to Prof. WrstzNBRINK.

References p. 86. 
minimus, M. vastus medialis, $M$. vastus intermedius, M. semitendinosus and $M$. soleus as representatives of the red muscles. Most experiments were, however, carried out with the mixed white muscles of the upper part of the legs.

Fat, nerves, tendons and connective tissue were removed. The muscles were then weighed, minced with scissors and ground in a mortar with an equal weight of sand. After a few minutes' grinding some solution used for extraction was added in order to prevent the $\mathrm{pH}_{\mathrm{H}}$ from dropping too much. Gradually more solution was added, until after a quarter of an hour the total amount necessary for extraction had been added (if not stated otherwise $I \mathrm{ml}$ per $\mathrm{g}$ of muscle).

The following solutions were used for extraction ( $\mu=$ ionic strength):

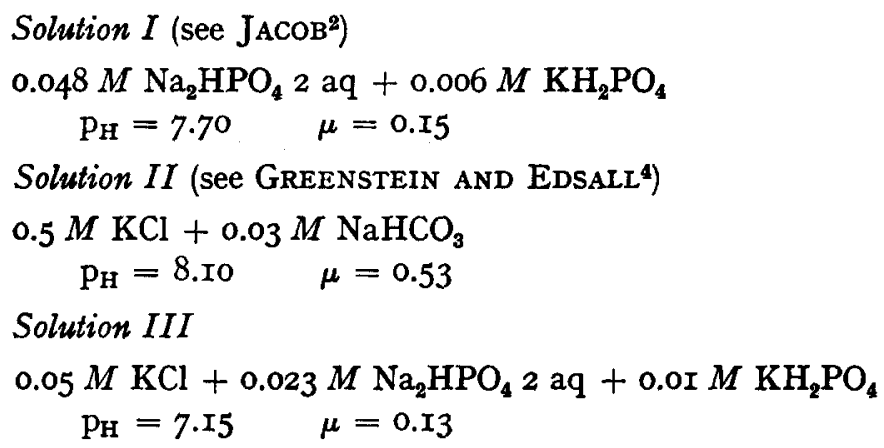

The muscle debris and the sand were spun down by 5 minutes' centrifuging at $600 \times \mathrm{g}$, in earlier experiments about one hour after grinding, in later ones immediately. The very viscous supernatant was dialyzed (see also Discussion).

2. Smooth muscle (stomach). Immediately after bleeding the rabbit, while the leg muscles were allowed to cool, the stomach was isolated and opened, the contents removed, and the inner wall cleaned and dried by means of plugs of cotton wool. The mucous membrane was then removed by rubbing cautiously with sand, after which the muscle surface was cleaned and dried again with cotton wool. The muscular tissue was further treated as described for the striated muscles.

\section{Dialysis}

20 to $40 \mathrm{ml}$ of extract in cellophane tubing (Kalle and Co, Wiesbaden, Germany) were dialysed at $3^{\circ} \mathrm{C}$ against $400 \mathrm{ml}$ of one of the following solutions:

\section{Solution III}

For composition see above

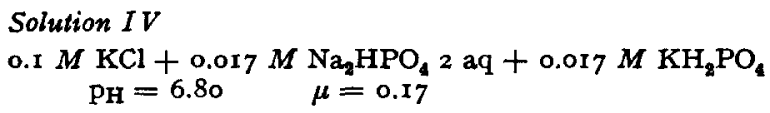

A protein precipitate, separating in the first few hours of dialysis was removed by 5 minutes' centrifuging at 10,000 $\times$ g. The supernatant, about half the initial volume, had lost the initial high viscosity of the extract and was much more suitable for dialysis. Dialysis was resumed for at least 12 hours, against fresh solution until the extract was used for electrophoresis. If the dialysis was continued for several days the outer solution was renewed every day.

The dialysed extract was centrifuged 15 minutes at $10,000 \times \mathrm{g}$ just before electrophoresis.

\section{Electrophoresis}

The electrophoresis was carried out in a Tisen.Ius apparatus with the optical equipment of Philpot-Svensson, as manufactured by Strübin and Co., Basle, Switzerland. The high cell type with $84 \mathrm{~mm}$ effective height was used in all experiments. If necessary the protein solutions were diluted by adding a salt solution of the same composition as used in dialysis, so that the protein concentration never exceeded $2.3 \%$. This salt solution was also used as a supernatant in the electrophoresis cell.

The following abbreviations will be used:

$i$ : strength of the current passing through the cell in Amperes

$E$ : potential applied to the electrodes in Volts

References p. 86. 
$K$ : conductivity of a solution in $\mathrm{Ohm}^{-1} \mathrm{~cm}^{-1}$

$\Theta:$ angle of inclination of the second slit

$t$ : time in seconds, during which the boundaries have moved under influence of the electric field.

The potential difference $E$ at the electrodes, which showed a tendency to change a little (about $5 \mathrm{~V}$ ) in the course of an experiment, was adjusted so as to maintain the current $i$ at a constant level. The data pertaining to the experiments carried out with Solutions III and IV are the following:

$\begin{array}{ccccc} & i & E & E i & K \\ \text { Salt solution III. } & 0.035 \mathrm{~A} & 225 \mathrm{~V} & 7.9 \mathrm{~W} & 0.00623 \mathrm{Ohm}^{-1} \mathrm{~cm}^{-1} \\ \text { Salt solution IV. } & 0.038 \mathrm{~A} & \mathrm{r} 7 \mathrm{OV} & 6.5 \mathrm{~W} & 0.00948 \mathrm{Ohm}^{-1} \mathrm{~cm}^{-1}\end{array}$

With these values for E $i$ no large convection disturbances, as described by ALVAREz Tostados, were observed.

The formation of gas at the electrodes could be prevented by using them alternatively as anode and cathode. Ilford Pan F Film, $35 \mathrm{~mm}, 25^{\circ} \mathrm{S}$, was used and a red filter was mounted to prevent the passage of rays of a wave length shorter than $600 \mu \mathrm{m}$.

The diagrams were analysed according to PeDrRsen's $s^{6}$ method by projecting them on paper, drawing a pencil line through the middle of the projected curves and fitting in, if possible symmetrical, Gauss-curves by trial and error employing the standard Gauss-curves of WIEDEMANN? ${ }^{\text {? }}$ The area of each gradient was calculated and expressed as a percentage of the total area of the diagram, which was measured by means of a planimeter.

\section{RESULTS}

\section{Reproducibility}

As will be demonstrated below the protein pattern of an extract alters during storage at $2^{\circ} \mathrm{C}$. Hence in controlling the accuracy with which a diagram of a muscle extract can be reproduced electrophoresis experiments should be made at the shortest possible intervals of time. Fig. I shows an example of two diagrams obtained on subsequent days with samples of one batch of dialyzed extract in Solution IV. If these diagrams are projected onto a sheet of white paper (magnification io $\times$ to a basis length of $34.5 \mathrm{~cm}$ ) they can be made to cover each other so completely that no differences can be detected by visual inspection.

This similarity is not observed on subsequent days when Solution III is used, in which the diagrams show more details. Diagrams in Solution III are only identical by visual inspection of the superposed projections when they have been obtained on the same day. The identity, in Solution IV as well as in Solution III, is of course only observed when $t, \Theta$ and $i$ are identical in the corresponding experiments.

No differences can be detected either between diagrams of extracts prepared with Solution III from various samples of one batch of minced muscle, if the extracts are prepared and the diagrams are made under conditions, as similar as possible. Fig. 2 gives two examples of these diagrams in Solution III.

All diagrams have been recorded 3 to 5 minutes after interruption of the current. If they were made without interruption of the current (the time of exposure was 30 seconds or less) or immediately after its interruption slight irreproducible irregularities in the curves of the type as shown in Fig. 3, were observed.

We have further studied the variation in the area attributed to the different components as expressed in percentages of the total area of the diagram (the "proteinpercentages") and the variation of the mobilities of the components as calculated from diagrams which are identical on superposed projection, and from the diagrams of exp. No. I48, which have been obtained with the same material but with another time of development of the pattern. 
TABLE NUMERICAL EVALUATION OF DIAGRAMS IDENTICAL UPON a. The area of the Gauss-curves fitted in the

\begin{tabular}{|c|c|c|c|c|c|c|c|}
\hline & & & & & & \multicolumn{2}{|c|}{ From diagrams 0} \\
\hline \multirow{2}{*}{$\begin{array}{l}\text { Rabbit } \\
\text { No. }\end{array}$} & \multirow{2}{*}{$\begin{array}{l}\text { Exp. } \\
\text { No. }\end{array}$} & \multirow{2}{*}{$\begin{array}{l}\text { Solution } \\
\text { No. }\end{array}$} & \multirow{2}{*}{$\begin{array}{c}t \\
(\mathrm{sec})\end{array}$} & \multicolumn{4}{|c|}{ Componen } \\
\hline & & & & 2 & 3 & 4 & 5 \\
\hline $\begin{array}{l}\text { III } \\
\text { III } \\
\text { III }\end{array}$ & $\begin{array}{l}148^{*} \\
149 \\
150\end{array}$ & $\begin{array}{l}\text { IV } \\
\text { IV } \\
\text { IV }\end{array}$ & $\begin{array}{l}21000 \\
22100 \\
22100\end{array}$ & $\begin{array}{l}5.2 \\
4.9 \\
4.0\end{array}$ & $\begin{array}{l}2.3 \\
5.3 \\
3.9\end{array}$ & $\begin{array}{l}\text { I1.9 } \\
13.7 \\
13.0\end{array}$ & $\begin{array}{l}7.2 \\
6.7 \\
8.4\end{array}$ \\
\hline \multicolumn{4}{|c|}{$\underset{\Sigma(A-x)^{2}}{\operatorname{mean}(A)}$} & $\begin{array}{l}4.7 \\
0.8\end{array}$ & $\begin{array}{l}3.8 \\
4.5\end{array}$ & $\begin{array}{r}\mathrm{I} 2.9 \\
\mathrm{I} .6\end{array}$ & $\begin{array}{l}7.4 \\
1.5\end{array}$ \\
\hline $\begin{array}{l}\text { III } \\
\text { III }\end{array}$ & $\begin{array}{l}155 \\
156\end{array}$ & IV & $\begin{array}{l}22000 \\
22010\end{array}$ & $\begin{array}{l}4.3 \\
4.4\end{array}$ & $\begin{array}{l}2.7 \\
2.6\end{array}$ & $\begin{array}{l}\text { II. } 5 \\
10.5\end{array}$ & $\begin{array}{l}8.3 \\
6.8\end{array}$ \\
\hline \multicolumn{4}{|c|}{$\begin{array}{c}\operatorname{mean}(A) \\
\Sigma(A-x)^{2}\end{array}$} & $\begin{array}{l}4 \cdot 4 \\
0.0\end{array}$ & $\begin{array}{l}2.7 \\
0.0\end{array}$ & $\begin{array}{r}\text { Ir.o } \\
0.5\end{array}$ & $\begin{array}{l}7.6 \\
1.1\end{array}$ \\
\hline $\begin{array}{l}\text { VIII } \\
\text { VIII } \\
\text { VIII } \\
\text { VIII }\end{array}$ & $\begin{array}{l}262 \\
263 \\
264 \\
265\end{array}$ & $\begin{array}{l}\text { III } \\
\text { III } \\
\text { III } \\
\text { III }\end{array}$ & $\begin{array}{l}13000 \\
13000 \\
13000 \\
13000\end{array}$ & $\begin{array}{l}3.5 \\
2.9 \\
2.9 \\
2.5\end{array}$ & & $\begin{array}{l}6.3 \\
7.7 \\
6.8 \\
7.5\end{array}$ & $\begin{array}{l}7.7 \\
8.7 \\
9.4 \\
8.9\end{array}$ \\
\hline \multicolumn{4}{|c|}{$\begin{array}{c}\operatorname{mean}(A) \\
\Sigma(A-x)^{2}\end{array}$} & $\begin{array}{l}3.0 \\
0.5\end{array}$ & & $\begin{array}{l}7.1 \\
1.3\end{array}$ & $\begin{array}{l}8.7 \\
2.5\end{array}$ \\
\hline \multicolumn{8}{|c|}{ From diagrams o } \\
\hline $\begin{array}{l}\text { III } \\
\text { III } \\
\text { III }\end{array}$ & $\begin{array}{l}148^{*} \\
149 \\
150\end{array}$ & $\begin{array}{l}\text { IV } \\
\text { IV } \\
\text { IV }\end{array}$ & $\begin{array}{l}21000 \\
21900 \\
21950\end{array}$ & $\begin{array}{l}5.1 \\
4.1 \\
5.0\end{array}$ & $\begin{array}{l}2.5 \\
3.3 \\
3.7\end{array}$ & $\begin{array}{l}\mathrm{I} 2.5 \\
\mathrm{x} 2.6 \\
\mathrm{I} 2.6\end{array}$ & $\begin{array}{r}8.0 \\
8.3 \\
10.4\end{array}$ \\
\hline \multicolumn{4}{|c|}{$\underset{\Sigma(A-x)^{\mathbf{z}}}{\operatorname{mean}(A)}$} & $\begin{array}{l}4.7 \\
0.7\end{array}$ & $\begin{array}{l}3.2 \\
0.8\end{array}$ & $\begin{array}{r}\mathrm{I} 2.6 \\
0.0\end{array}$ & $\begin{array}{l}8.9 \\
3.4 \\
\end{array}$ \\
\hline $\begin{array}{l}\text { III } \\
\text { III }\end{array}$ & $\begin{array}{l}155 \\
156\end{array}$ & $\begin{array}{l}\text { IV } \\
\text { IV }\end{array}$ & $\begin{array}{l}22000 \\
22010\end{array}$ & $\begin{array}{l}4.1 \\
3.6\end{array}$ & $\begin{array}{l}2.7 \\
2.5\end{array}$ & $\begin{array}{l}15.0 \\
\text { I3.7 }\end{array}$ & $\begin{array}{l}8.4 \\
9.3\end{array}$ \\
\hline \multicolumn{4}{|c|}{$\Sigma(A-x)^{2}$} & $\begin{array}{l}3.9 \\
0.1\end{array}$ & $\begin{array}{l}2.6 \\
0.0\end{array}$ & $\begin{array}{r}14.4 \\
0.9\end{array}$ & $\begin{array}{l}8.9 \\
0.4\end{array}$ \\
\hline $\begin{array}{l}\text { VIII } \\
\text { VIII } \\
\text { VIII } \\
\text { VIII }\end{array}$ & $\begin{array}{l}262 \\
263 \\
264 \\
265\end{array}$ & $\begin{array}{l}\text { III } \\
\text { III } \\
\text { III } \\
\text { III }\end{array}$ & $\begin{array}{l}13000 \\
13000 \\
13000 \\
13000\end{array}$ & $\begin{array}{l}3.4 \\
2.9 \\
3.6 \\
2.6\end{array}$ & & $\begin{array}{r}7.3 \\
10.7 \\
10.6 \\
10.3\end{array}$ & $\begin{array}{r}8.8 \\
10.1 \\
10.7 \\
8.4\end{array}$ \\
\hline \multicolumn{4}{|c|}{$\begin{array}{l}\operatorname{mean}(A) \\
\Sigma(A-x)^{\mathbf{2}}\end{array}$} & $\begin{array}{l}3 . r \\
0.6\end{array}$ & & $\begin{array}{l}9.7 \\
8.0\end{array}$ & $\begin{array}{l}9.5 \\
3.1\end{array}$ \\
\hline
\end{tabular}

For components $2,3,4,5,6: \quad$ Standard deviation $=\sqrt{\frac{\Sigma \Sigma(A-x)^{2}}{n-I}}=\sqrt{\frac{37.6}{74-1}}=0.7 \%$

For components $7,8,9: \quad$ Standard deviation $=\sqrt{\frac{\sum \Sigma(A-x)^{2}}{n-I}}=\sqrt{\frac{110.0}{44-1}}=1.6 \%$

References p. 86 . 
I

VISUAL INSPECTION OF SUPERPOSED PROJECTIONS

diagrams expressed in percentages of the total area

\begin{tabular}{|c|c|c|c|c|c|c|c|c|}
\hline \multicolumn{9}{|c|}{ descending boundaries } \\
\hline \multicolumn{4}{|c|}{ Component } & \multirow{2}{*}{$\begin{array}{c}\text { Sum of } \\
\text { components }\end{array}$} & \multirow{2}{*}{$\begin{array}{c}\delta \text { or } \varepsilon \\
\text { gradient }\end{array}$} & \multirow{2}{*}{$\begin{array}{l}\text { Tot. area } \\
\left(\mathrm{cm}^{2}\right)\end{array}$} & \multirow{2}{*}{$\begin{array}{c}\text { Age of } \\
\text { extract } \\
\text { (days) }\end{array}$} & \\
\hline 6 & 7 & 8 & 9 & & & & & \\
\hline $\begin{array}{l}4.8 \\
5.0 \\
6.0\end{array}$ & $\begin{array}{l}27.8 \\
29.4 \\
26.4\end{array}$ & $\begin{array}{l}25.0 \\
26.0 \\
26.8\end{array}$ & & $\begin{array}{l}88.6 \\
91.0 \\
88.5\end{array}$ & $\begin{array}{l}13.9 \\
12.5 \\
14.0\end{array}$ & $\begin{array}{r}109 \\
75 \\
78\end{array}$ & $\begin{array}{l}3 \\
4 \\
5\end{array}$ & \\
\hline $\begin{array}{l}5 \cdot 3 \\
0.9\end{array}$ & $\begin{array}{r}27.9 \\
4.5\end{array}$ & $\begin{array}{r}25.9 \\
1.6\end{array}$ & & 89.0 & 13.5 & 一 & - & \\
\hline $\begin{array}{l}5.2 \\
4.8\end{array}$ & $\begin{array}{l}37.0 \\
34.6\end{array}$ & $\begin{array}{l}22.8 \\
18.5\end{array}$ & & $\begin{array}{l}91.5 \\
82.2\end{array}$ & $\begin{array}{l}6.9 \\
6.9\end{array}$ & $\begin{array}{l}\text { IOI } \\
\text { I I I }\end{array}$ & $\begin{array}{l}\text { IO } \\
\text { I I }\end{array}$ & $\begin{array}{l}\text { See Fig. Ia } \\
\text { See Fig. Ib }\end{array}$ \\
\hline $\begin{array}{l}5.0 \\
0.1\end{array}$ & $\begin{array}{r}35.8 \\
2.9\end{array}$ & $\begin{array}{r}20.7 \\
9.2\end{array}$ & & 86.9 & 6.9 & - & - & \\
\hline $\begin{array}{l}2.9 \\
4.2 \\
3.0 \\
4.8\end{array}$ & $\begin{array}{l}30.0 \\
26.8 \\
21.9 \\
28.0\end{array}$ & $\begin{array}{l}20.6 \\
22.8 \\
25.5 \\
27.2\end{array}$ & $\begin{array}{r}19.6 \\
15.1 \\
9.2 \\
11.7\end{array}$ & $\begin{array}{l}90.6 \\
88.2 \\
95.0 \\
90.6\end{array}$ & $\begin{array}{l}5.7 \\
6.5 \\
5.9 \\
5.6\end{array}$ & $\begin{array}{l}85 \\
92 \\
83 \\
88\end{array}$ & $\begin{array}{l}2 \\
2 \\
3 \\
3\end{array}$ & $\begin{array}{l}\text { See Fig. } 2 \\
\text { See Fig. } 2\end{array}$ \\
\hline $\begin{array}{l}3.7 \\
2.6\end{array}$ & $\begin{array}{l}26.7 \\
35.6\end{array}$ & $\begin{array}{l}24.0 \\
25.5\end{array}$ & $\begin{array}{l}\text { I } 7 \cdot 3^{\star \star} \\
10.5^{\star \star \star} \\
\text { I } 3.2\end{array}$ & 9I.I & $5 \cdot 9$ & - & - & \\
\hline
\end{tabular}

ascending boundaries

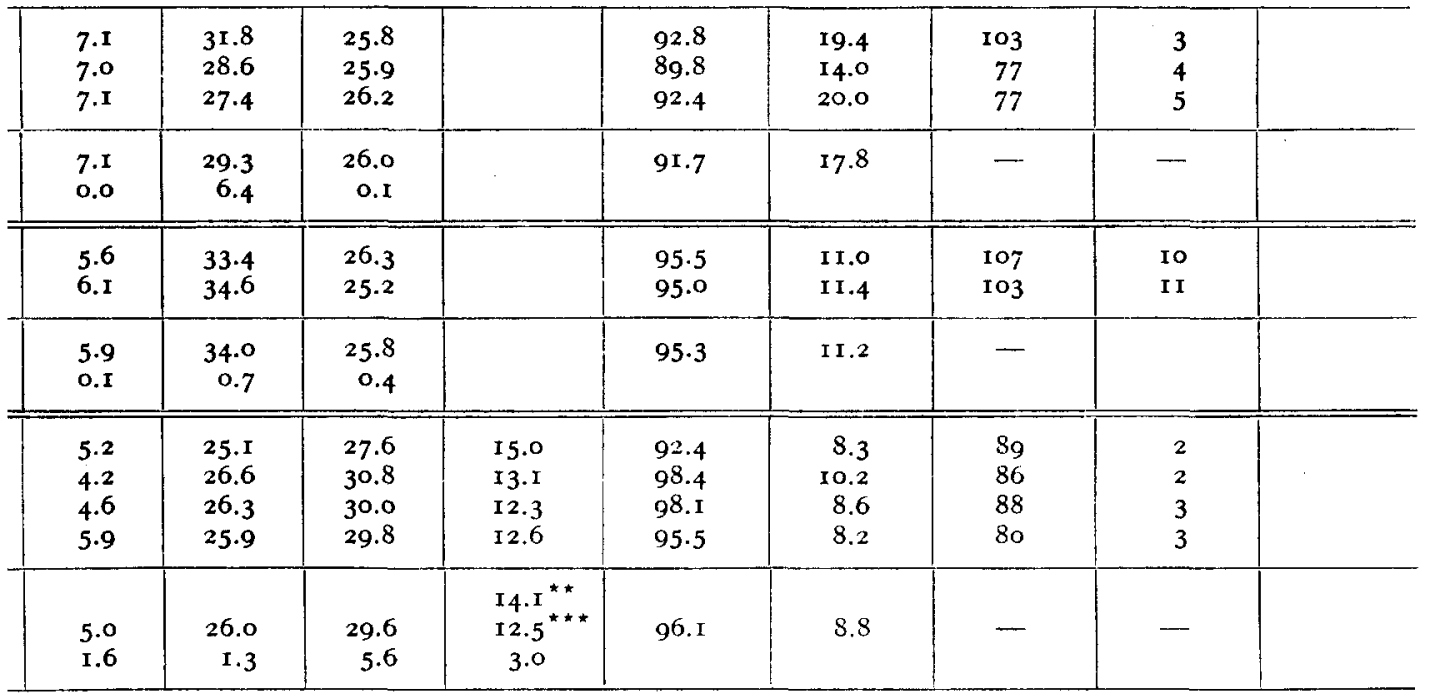

* Experiment performed with same extract as used in exp. I 49 and I50. Only as a consequence of a shorter time of electrophoresis the diagrams were not identical with the diagrams of exp. I 49 and I 50 upon visual inspection of the superposed projections.

** Age of extracts 2 days.

** Age of extracts 3 days.

References $p .86$. 
TABLE I

b. Mobilities in

From diagrams of

\begin{tabular}{|c|c|c|c|c|c|c|}
\hline \multirow{2}{*}{$\begin{array}{c}\text { Rabbit } \\
\text { No. }\end{array}$} & \multirow{2}{*}{$\begin{array}{l}\text { Exp. } \\
\text { No. }\end{array}$} & \multirow{2}{*}{$\begin{array}{c}\text { Solution } \\
\text { No. }\end{array}$} & \multirow{2}{*}{$\begin{array}{c}t \\
(\sec )\end{array}$} & \multicolumn{3}{|c|}{ Component } \\
\hline & & & & 2 & 3 & 4 \\
\hline $\begin{array}{l}\text { III } \\
\text { III } \\
\text { III }\end{array}$ & $\begin{array}{l}148 \\
149 \\
150\end{array}$ & $\begin{array}{l}\text { IV } \\
\text { IV } \\
\text { IV }\end{array}$ & $\begin{array}{l}21000 \\
22100 \\
22100\end{array}$ & $\begin{array}{l}4.8 \\
4 \cdot 7 \\
4.8\end{array}$ & $\begin{array}{l}2.4 \\
2.8 \\
2.5\end{array}$ & $\begin{array}{l}2.0 \\
1.9 \\
1.9\end{array}$ \\
\hline \multicolumn{4}{|c|}{$\underset{\Sigma(A-x)^{2}}{\operatorname{mean}(A)}$} & $\begin{array}{l}4.8 \\
0.01\end{array}$ & $\begin{array}{l}2.6 \\
0.09\end{array}$ & $\begin{array}{l}1.9 \\
0.01\end{array}$ \\
\hline $\begin{array}{l}\text { III } \\
\text { III }\end{array}$ & $\begin{array}{l}\text { I } 55 \\
\text { I } 56\end{array}$ & $\begin{array}{l}\text { IV } \\
\text { IV }\end{array}$ & $\begin{array}{l}22000 \\
22010\end{array}$ & $\begin{array}{l}4.8 \\
4.7\end{array}$ & $\begin{array}{l}2.4 \\
2.3\end{array}$ & $\begin{array}{l}2.0 \\
1.9\end{array}$ \\
\hline \multicolumn{4}{|c|}{$\underset{\Sigma(A-x)^{2}}{\operatorname{mean}(A)}$} & $\begin{array}{l}4.8 \\
0.01\end{array}$ & $\begin{array}{l}2.4 \\
0.01\end{array}$ & $\begin{array}{l}2.0 \\
0.01\end{array}$ \\
\hline $\begin{array}{l}\text { VIII } \\
\text { VIII } \\
\text { VIII } \\
\text { VIII }\end{array}$ & $\begin{array}{l}262 \\
263 \\
264 \\
265\end{array}$ & $\begin{array}{l}\text { III } \\
\text { III } \\
\text { III } \\
\text { III }\end{array}$ & $\begin{array}{l}\text { I 3000 } \\
\text { I 3000 } \\
\text { I 3000 } \\
\text { I } 3000\end{array}$ & $\begin{array}{l}6.5 \\
6.4 \\
6.3 \\
6.6\end{array}$ & & $\begin{array}{l}2.9 \\
2.8 \\
2.7 \\
2.9\end{array}$ \\
\hline \multicolumn{4}{|c|}{$\Sigma \underset{(A-x)^{2}}{\operatorname{mean}(A)}$} & $\begin{array}{l}6.5 \\
0.06\end{array}$ & & $\begin{array}{l}2.8 \\
0.03\end{array}$ \\
\hline
\end{tabular}

From diagrams of

\begin{tabular}{|c|c|c|c|c|c|c|}
\hline $\begin{array}{l}\text { III } \\
\text { III } \\
\text { III }\end{array}$ & $\begin{array}{l}\text { I } 48 \\
\text { I } 49 \\
\text { I } 50\end{array}$ & $\begin{array}{l}\text { IV } \\
\text { IV } \\
\text { IV }\end{array}$ & $\begin{array}{l}21000 \\
21900 \\
21950\end{array}$ & $\begin{array}{l}5.1 \\
5.0 \\
5.0\end{array}$ & $\begin{array}{l}2.9 \\
3.0 \\
3.1\end{array}$ & $\begin{array}{l}2.4 \\
2.4 \\
2.4\end{array}$ \\
\hline \multicolumn{4}{|c|}{$\operatorname{mean}_{\Sigma(A-x)^{2}}$} & $\begin{array}{l}5.0 \\
0.01\end{array}$ & $\begin{array}{l}3.0 \\
0.02\end{array}$ & $\begin{array}{l}2.4 \\
0.00\end{array}$ \\
\hline $\begin{array}{l}\text { III } \\
\text { III }\end{array}$ & $\begin{array}{l}\text { I } 55 \\
\text { I } 56\end{array}$ & $\begin{array}{l}\text { IV } \\
\text { IV }\end{array}$ & $\begin{array}{l}22000 \\
22010\end{array}$ & $\begin{array}{l}4.9 \\
5.0\end{array}$ & $\begin{array}{l}2.9 \\
2.8\end{array}$ & $\begin{array}{l}2.3 \\
2.3\end{array}$ \\
\hline \multicolumn{4}{|c|}{$\underset{\Sigma(A-x)^{2}}{\operatorname{mean}(A)}$} & $\begin{array}{l}5.0 \\
0.01\end{array}$ & $\begin{array}{l}2.9 \\
0.0 \mathrm{I}\end{array}$ & $\begin{array}{l}2.3 \\
0.00\end{array}$ \\
\hline $\begin{array}{l}\text { VIII } \\
\text { VIII } \\
\text { VIII } \\
\text { VIII }\end{array}$ & $\begin{array}{l}262 \\
263 \\
264 \\
265\end{array}$ & $\begin{array}{l}\text { III } \\
\text { III } \\
\text { III } \\
\text { III }\end{array}$ & $\begin{array}{l}13000 \\
13000 \\
13000 \\
13000\end{array}$ & $\begin{array}{l}6.5 \\
6.4 \\
6.2 \\
6.4\end{array}$ & & $\begin{array}{l}3.2 \\
3.2 \\
3.2 \\
3.2\end{array}$ \\
\hline \multicolumn{4}{|c|}{$\underset{\Sigma(A-x)^{2}}{\operatorname{mean}(A)}$} & $\begin{array}{l}6.4 \\
0.05\end{array}$ & & $\begin{array}{l}3.2 \\
0.00\end{array}$ \\
\hline
\end{tabular}

Standard deviation $=\sqrt{\frac{\sum \Sigma(A-x)^{2}}{n-I}}=\sqrt{\frac{0.63 \cdot 10^{-10}}{126-I}}=0.07 \cdot 10^{-5} \mathrm{~cm}^{2} \mathrm{Volt}^{-1} \mathrm{sec}^{-1}$ 
(Continued)

${ }^{10^{-6}} \mathrm{~cm}^{2}$ Volt $^{-1} \mathrm{sec}^{-1}$

descending boundaries

\begin{tabular}{|c|c|c|c|c|c|c|c|}
\hline \multicolumn{5}{|c|}{ Component } & \multirow{2}{*}{$\begin{array}{c}\delta \text { or } \varepsilon \\
\text { gradient }\end{array}$} & \multirow{2}{*}{$\begin{array}{l}\text { Age of } \\
\text { extract } \\
\text { (days) }\end{array}$} & \\
\hline 5 & 6 & 7 & 8 & 9 & & & \\
\hline $\begin{array}{l}1.7 \\
1.6 \\
1.6\end{array}$ & $\begin{array}{l}\text { I. } 2 \\
1.1 \\
1.1\end{array}$ & $\begin{array}{l}0.8 \\
0.8 \\
0.8\end{array}$ & $\begin{array}{l}0.5 \\
0.5 \\
0.5\end{array}$ & & $\begin{array}{r}+0.2 \\
0.0 \\
+0.4\end{array}$ & $\begin{array}{l}3 \\
4 \\
5\end{array}$ & \\
\hline $\begin{array}{l}1.6 \\
0.01\end{array}$ & $\begin{array}{l}\text { I.I } \\
\text { O.OI }\end{array}$ & $\begin{array}{l}0.8 \\
0.00\end{array}$ & $\begin{array}{l}0.5 \\
0.00\end{array}$ & & - & - & \\
\hline $\begin{array}{l}1.7 \\
1.6\end{array}$ & $\begin{array}{l}1.3 \\
1.2\end{array}$ & $\begin{array}{l}0.8 \\
0.8\end{array}$ & $\begin{array}{l}0.5 \\
0.5\end{array}$ & & $\begin{array}{r}0.0 \\
+\quad 0.2\end{array}$ & $\begin{array}{l}\text { Io } \\
\text { II }\end{array}$ & $\begin{array}{l}\text { See Fig. Ia } \\
\text { See Fig. Ib }\end{array}$ \\
\hline $\begin{array}{l}1.7 \\
0.01\end{array}$ & $\begin{array}{l}1.3 \\
0.0 \mathrm{r}\end{array}$ & $\begin{array}{l}0.8 \\
0.00\end{array}$ & $\begin{array}{l}0.5 \\
0.00\end{array}$ & & - & - & \\
\hline $\begin{array}{l}2.5 \\
2.4 \\
2.4 \\
2.5\end{array}$ & $\begin{array}{l}2.1 \\
1.9 \\
1.9 \\
1.9\end{array}$ & $\begin{array}{l}\text { I.6 } \\
\text { I.5 } \\
\text { I.5 } \\
\text { I. } 6\end{array}$ & $\begin{array}{l}1.2 \\
1.0 \\
1.0 \\
1.1\end{array}$ & $\begin{array}{l}0.8 \\
0.7 \\
0.6 \\
0.6\end{array}$ & $\begin{array}{l}+0.1 \\
+0.2 \\
+0.6 \\
+0.7\end{array}$ & $\begin{array}{l}2 \\
2 \\
3 \\
3\end{array}$ & $\begin{array}{l}\text { See Fig. } 2 \\
\text { See Fig. } 2\end{array}$ \\
\hline $\begin{array}{l}2.5 \\
0.02\end{array}$ & $\begin{array}{l}1.9 \\
0.04\end{array}$ & $\begin{array}{l}1.6 \\
0.02\end{array}$ & $\begin{array}{l}\text { I. I } \\
0.03\end{array}$ & $\begin{array}{l}0.7 \\
0.03\end{array}$ & - & - & \\
\hline
\end{tabular}

ascending boundaries

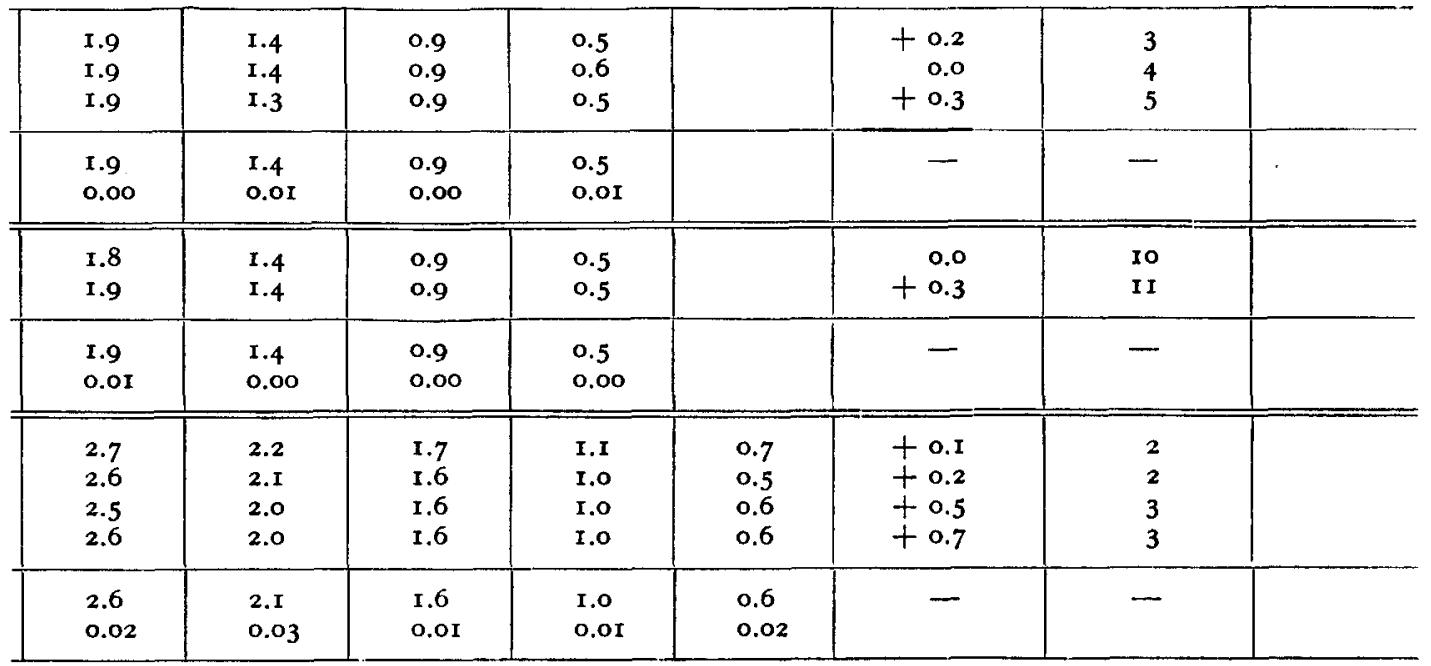



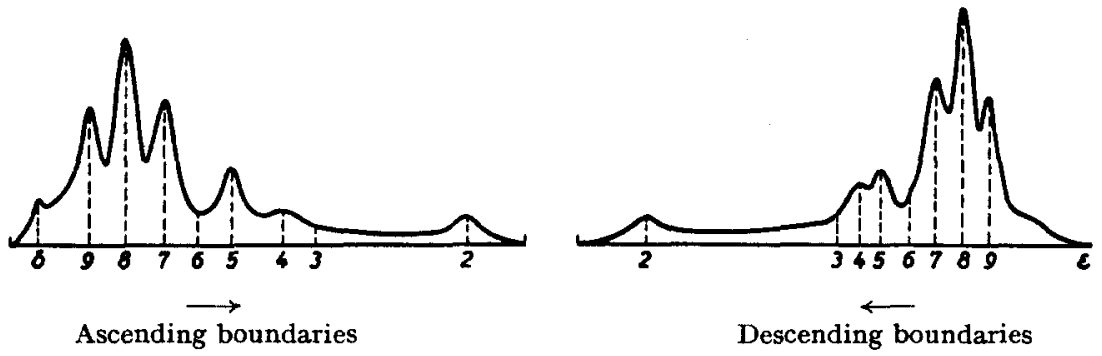

Fig. 4. Numbering of protein components

We believe that the differences between results calculated from various diagrams, identical upon superposed projection, must be attributed to the difficulty in drawing a pencil line exactly through the middle of the projected curves and to the arbitrariness inharent in the choice of the Gauss curves.

The results of the calculations are given in Table I (for numbering of components see Fig. 4).

Regarding the protein-percentages it should be kept in mind that Pedersen's method for analysis of the diagrams has been used. If the diagrams had been analyzed according to TISELIUS AND KABAT's method ${ }^{8}$ somewhat different values would probably have been obtained (see LONGSWORTH ${ }^{9}$ ).

Component $\mathrm{I}$, having the highest mobility $\left(c .6 .8 \cdot 10^{-5} \mathrm{~cm}^{2}\right.$ Voltt-1 $\mathrm{sec}^{-1}$ in Solution III) was always present, but in too small an amount (it occupied less than $I \%$ of the total area of the diagram) for exact numerical evaluation. For this reason the numbering of components in Table I begins with 2. The evaluation of the $\delta$ and $\varepsilon$ gradients in the diagrams obtained with Solution IV is difficult as they are not sufficiently separated from the neighbouring protein gradient.

The overlapping of gradients $2,3,4,5$ and 6 by neighbouring gradients is smaller than in the case of gradients 7,8 and 9 . Therefore standard deviations have been calculated for both groups separately. The mobilities have been calculated with respect to the $\delta$ (or $\varepsilon$ ) gradient. The apparent mobilities of the $\delta$ and $\varepsilon$ gradients with respect to the initial boundaries (caused by a movement of the liquid in the cell as a whole) are also listed in Table $I$.

In the case we wish to establish the identity or non-identity of two diagrams obtained under identical conditions the most suitable method is superposed projection, as demonstrated above. However it is not always possible to obtain diagrams under the chosen conditions. In that case we can only establish the identity or non-identity of diagrams with a certain probability by means of the calculated standard deviations.

\section{INFLUENCE ON THE ELECTROPHORESIS DIAGRAMS OF THE SALT SOLUTION USED FOR DIALYSIS AND ELECTROPHORESIS}

In order to obtain the diagrams most suitable for the characterization of extracts of striated muscle the influence on the diagrams of the composition of the salt solution used for dialysis and electrophoresis was studied.

A large amount of extract was prepared using Solution I. It was dialyzed against Solution IV for four days. The protein precipitate formed was separated by 5 minutes' References p. 86. 


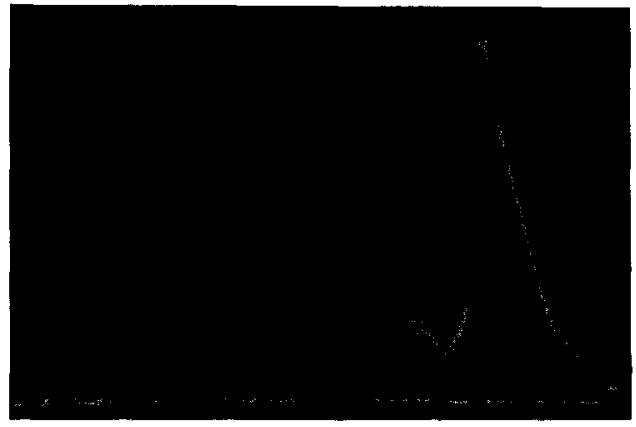

a

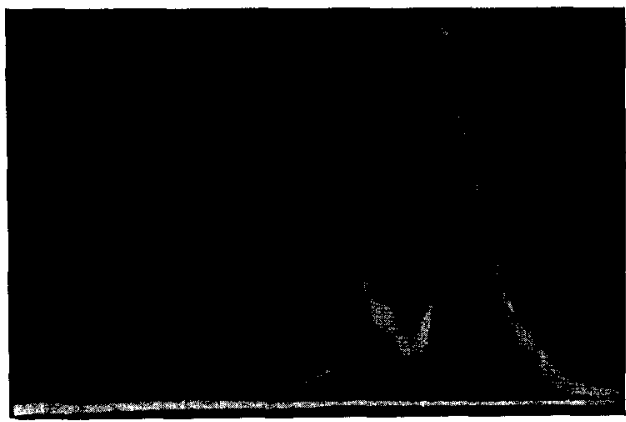

b

Fig. I. Examples of diagrams obtained with various samples of one batch of extract Rabbit III. Musc. vastus lateralis. Extractive: Solution I. Dialysis and electrophoresis with Solution IV. $E=\mathrm{I} 70 \mathrm{~V} ; i=0.038 \mathrm{~A} ; \Theta=55^{\circ}$ Desc.

a. $t=22$, ooo sec. Age of extract: I I days. Table I, exp. 155. b. $t=22$,oro sec. Age of extract: I2 days. Table I, exp. I56.

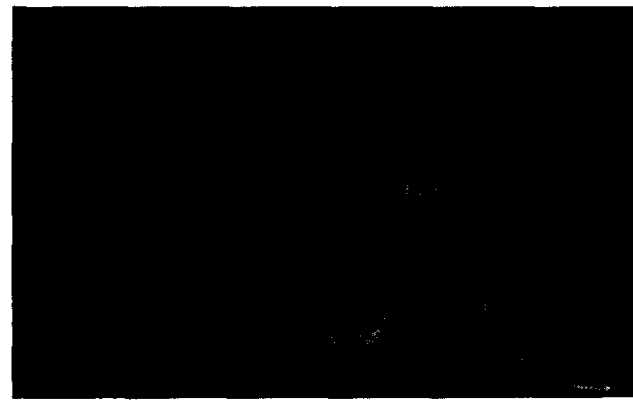

a

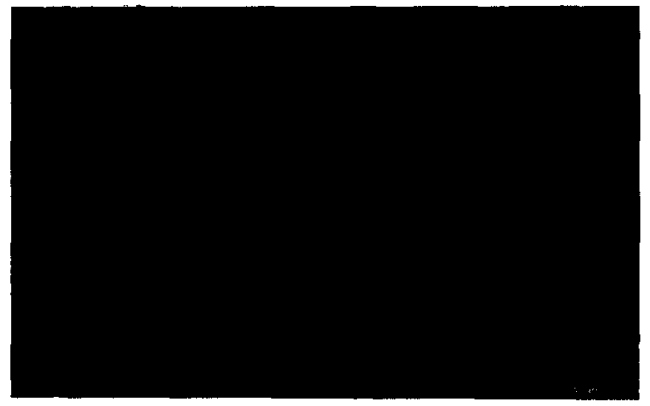

b

Fig. 2. Examples of diagrams obtained with various samples of one batch of extract

Rabbit VIII. Mixed white muscles. Extraction, dialysis and electrophoresis with Solution III. $E=225 \mathrm{~V} ; i=0.03^{8 \mathrm{~A}} ; t=\mathrm{I} 3,000 \mathrm{sec} ; \Theta=55^{\circ}$ Desc. Age of extract: 2 days. Table I, exp. 262, 263 .

Fig. 3. Diagram obtained without interruption of the current To be compared with Fig. 2b. Legend: see Fig. 2. 
centrifuging at $10,000 \times \mathrm{g}$. Of the supernatant eight portions of $15 \mathrm{ml}$ each were dialyzed against one of the following salt solutions, until the moment they were subjected to electrophoresis in the following order:

Solution $A$

$0.025 M$ veronal-Na $+0.125 M \mathrm{NaCl}+0.0229 M \mathrm{HCl}$

$$
\mathrm{p}_{\mathrm{H}}=6.80 \quad \mu=0.15
$$

\section{Solution $B$}

$$
\begin{gathered}
0.034 M \mathrm{Na}_{2} \mathrm{HPO}_{4} 2 \mathrm{aq}+0.034 M \mathrm{KH}_{2} \mathrm{PO}_{4} \\
\mathrm{p}_{\mathrm{H}}=6.80 \quad \mu=0.14
\end{gathered}
$$

\section{Solution $C$}

$0.0257 M$ veronal-Na $+0.0257 M$ Na-acetate 3 aq $+0.05 M \mathrm{NaCl}+0.0234 M \mathrm{HCl}$

$$
\mathrm{p}_{\mathrm{H}}=6.80 \quad \mu=0.10
$$

\section{Solution $D$}

$$
\begin{aligned}
0.03 M \mathrm{KCl}+0.0 \mathrm{I} 7 M \mathrm{Na}_{2} \mathrm{HPO}_{4} 2 \mathrm{aq}+\text { o.oI } M \mathrm{KH}_{2} \mathrm{PO}_{4} \\
\mathrm{p}_{\mathrm{H}}=6.8 \mathrm{o} \quad \mu=0 . \mathrm{IO}
\end{aligned}
$$

Solution $E[=$ Solution $I V)$

$$
\begin{gathered}
\text { o.I } M \mathrm{KCl}+\text { o.or7 } M \mathrm{Na}_{2} \mathrm{HPO}_{4} 2 \mathrm{aq}+0.0 \mathrm{I} 7 M \mathrm{KH}_{2} \mathrm{PO}_{4} \\
\mathrm{p}_{\mathrm{H}}=6.8 \mathrm{o} \quad \mu=0.17
\end{gathered}
$$

Solution $F(=$ Solution $I)$

$0.048 M \mathrm{Na}_{2} \mathrm{HPO}_{4} 2 \mathrm{aq}+0.006 \mathrm{M} \mathrm{KH}_{2} \mathrm{PO}_{4}$

$$
\mathrm{p}_{\mathrm{H}}=7.70 \quad \mu=0.15
$$

\section{Solution $G$}

0.or5 $M \mathrm{Na}_{4} \mathrm{P}_{2} \mathrm{OI}_{\text {Io aq }}+0.006 \mathrm{MHCl}$

$$
\mathrm{p}_{\mathrm{H}}=8.64 \quad \mu=0 . \mathrm{I} 3
$$

\section{Solution $H$}

$0.0286 M$ veronal-Na $+0.0286 M$ Na-acetate 3 aq $+0.09 M \mathrm{NaCl}+0.0036 M \mathrm{HCl}$.

$$
\mathrm{p}_{\mathrm{H}}=8.60 \quad \mu=0.15
$$

When subjected to electrophoresis the age of the extracts varied from ro (diagrams in buffer A) to I 8 days (diagrams in buffer $\mathrm{H}$ ). As aging of the extract only influences component 9 and that mainly during the first week after extraction of the proteins from muscle (see following section), the differences between the diagrams obtained in the Solutions $\mathrm{A}$ to $\mathrm{H}$ must be ascribed to the different composition of these salt solutions.

The diagrams obtained are shown in Fig. 5a-h. From these diagrams it may be observed that the addition of acetate to a veronal solution has little or no influence upon the diagram (compare Fig. 5a and $5 \mathrm{c}$ ).

The diagrams obtained in veronal solution show marked differences as compared to those obtained in phosphate solution of approximately the same $\mathrm{p}_{\boldsymbol{H}}$ and $\mu$.

Further it has been demonstrated that by adding $\mathrm{KCl}$ to a solution of buffer salts small details are lost (compare Fig. $5 \mathrm{~b}, 5 \mathrm{~d}$ and $5 \mathrm{e}$ ) and that many details are lost when References p. 86. 

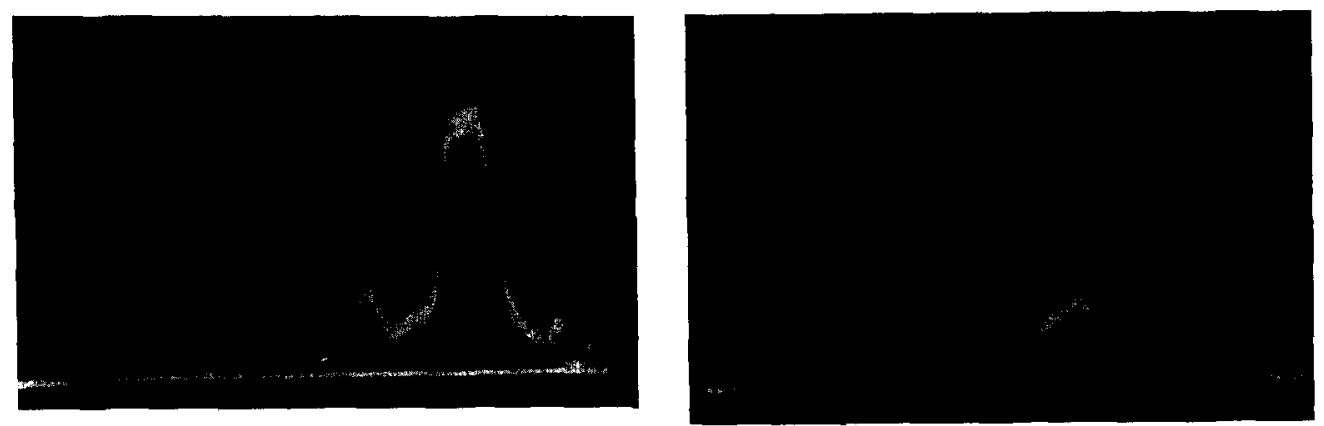

$\leftarrow$
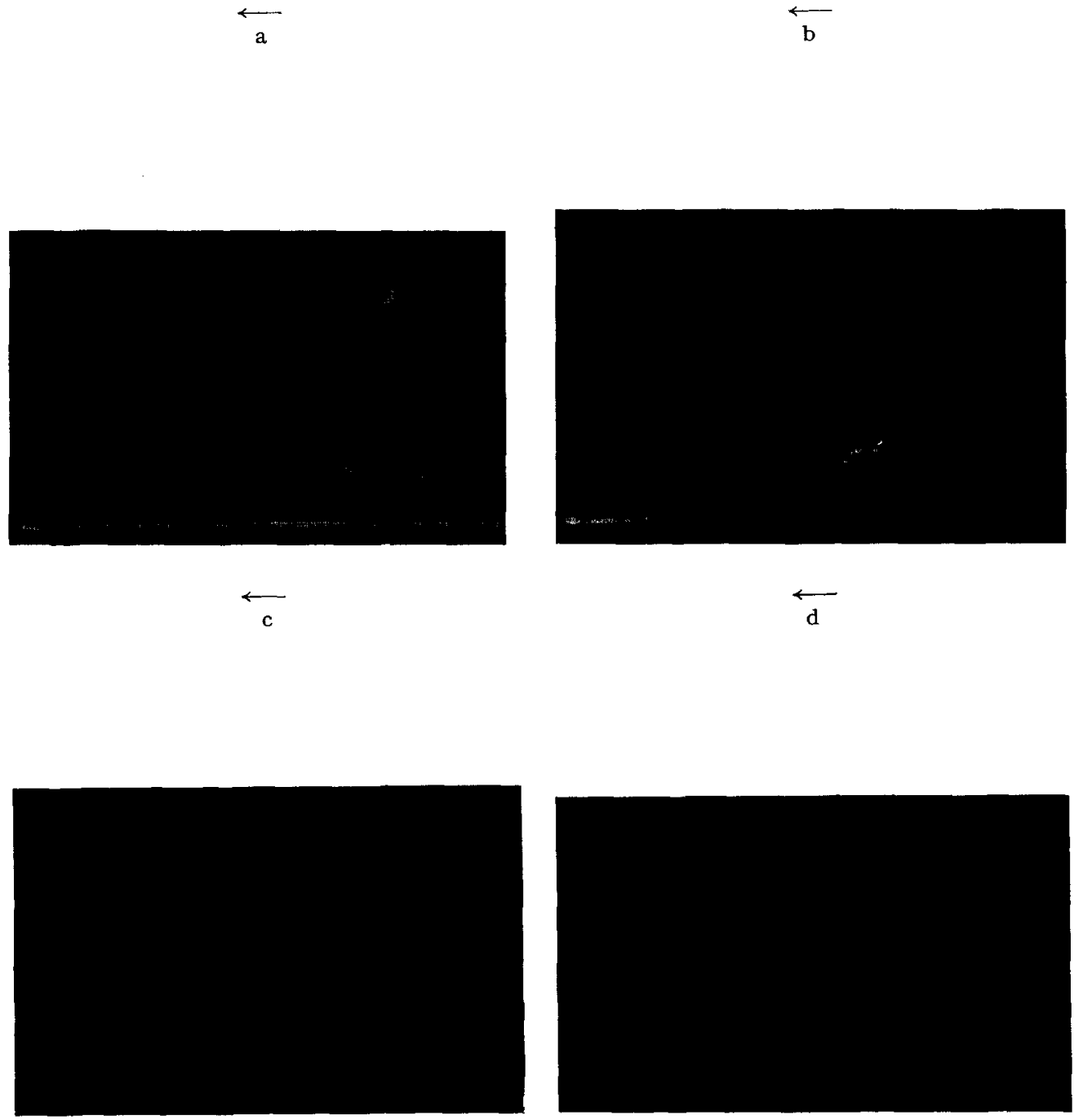

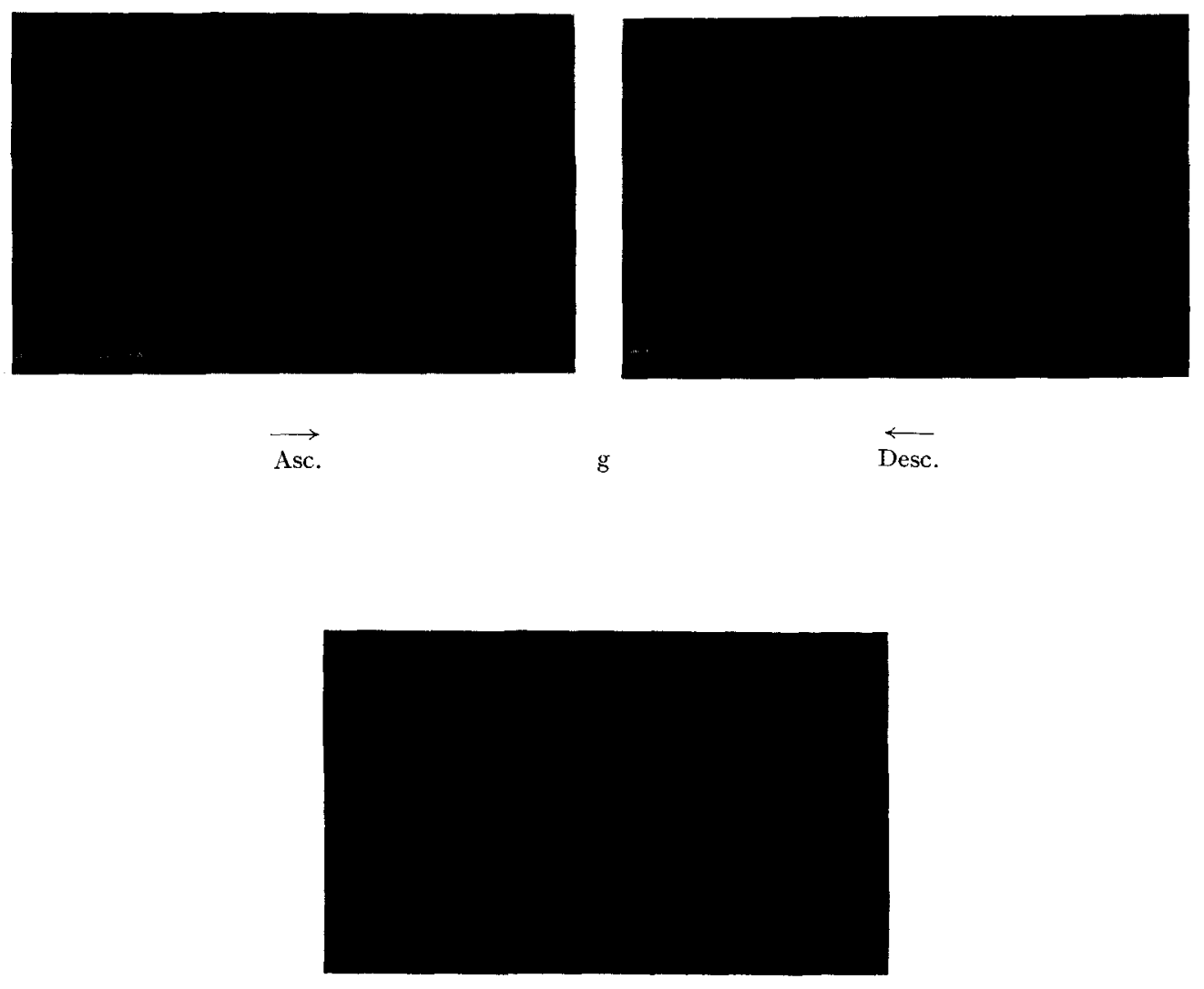

Fig. 5 (continued). The influence on the electrophoresis diagrams of the salt solution used for dialysis and electrophoresis

Rabbit IV. Mixed white muscles. Extraction and dialysis: see text.

a. Veronal-NaCl $\quad \mathrm{pH}_{E}=6.80, \mu=0$. I 5 $E=\mathrm{I} 8_{4} \mathrm{~V}, i=0.04 \circ \mathrm{A}, t=20,500 \mathrm{sec}, \Theta=55^{\circ}$ Desc.

b. Phosphate $\quad \mathrm{pH}=6.80, \mu=0.14$ $E=240 \mathrm{~V}, i=0.025 \mathrm{~A}, t=13,630 \mathrm{sec}, \Theta=55^{\circ}$ Desc.

c. Veronal-acetate- $\mathrm{NaCl} \mathrm{PH}=6.80, \mu=0$. 0 $E=195 \mathrm{~V}, i=0.040 \mathrm{~A}, t=19$, 000 sec, $\Theta=50^{\circ}$ Desc.

d. Phosphate-KCl $\quad \mathrm{pH}=6.8 \mathrm{o}, \mu=$ o. $\mathrm{Io}$ $E=220 \mathrm{~V}, i=0.025 \mathrm{~A}, t=\mathrm{I} 5,600 \mathrm{sec}, \Theta=55^{\circ}$ Desc.

e. Phosphate- $\mathrm{KCl} \quad \mathrm{pH}_{\mathrm{H}}=6.8 \mathrm{o}, \mu=0 . \mathrm{I} 7$ $E=\mathrm{I}_{7} 6 \mathrm{~V}, i=0.040 \mathrm{~A}, t=2 \mathrm{I}, 650 \mathrm{sec}, \Theta=50^{\circ}$ Desc.

f. Phosphate $\quad \mathrm{pH}=7.7^{\circ}, \mu=0.15$ $E=240 \mathrm{~V}, i=0.025 \mathrm{~A}, t=\mathrm{I} \mathrm{I}, 000 \mathrm{sec}, \Theta=55^{\circ}$ Desc.

g. Pyrophosphate- $\mathrm{NaCl} \mathrm{pH}_{\mathrm{H}}=8.64, \mu=0 . \mathrm{I}_{3}$ $E=320 \mathrm{~V}, i=0.020 \mathrm{~A}, t=5,220 \mathrm{sec}, \Theta=45^{\circ}$ Asc. and desc.

h. Veronal-acetate- $\mathrm{NaCl} \mathrm{pH}_{\mathrm{H}}=8.60, \mu=0 . \mathrm{I}_{5}$ $E=194 \mathrm{~V}, i=0.035 \mathrm{~A}, t=12,800 \mathrm{sec}, \Theta=50^{\circ}$ Desc.

References p. 86 . 
the $\mathrm{p}_{H}$ is shifted to a higher value (compare Fig. $5^{b}$ and $5 f$ ). The diagrams in the pyrophosphate solution $\mathrm{G}$ are very asymmetrical. Although the ionic strength is within the normal range ( $\mu=0.13$ ) the low molarity $(M=0.02 \mathrm{I})$ does not appear to be completely compensated in electrophoresis by the high charge of the pyrophosphate ions $\left(\mathrm{P}_{2} \mathrm{O}_{7}^{+4}\right.$ and $\mathrm{HP}_{2} \mathrm{O}_{7}^{+3}$ ). It is surprising how similar the figures are for the protein-percentages calculated from these diagrams (see Table II).

Solution $\mathbf{H}$ is frequently used for serum and plasma analysis; for these protein solutions it has definite advantages over other salt solutions (LONGSWORTH ${ }^{9}$ ). In our case, however, the patterns obtained with this salt solution are very poor in detail (Fig. 5h).

On the strength of these experiments we decided that a salt solution of the following composition would have the most favourable properties for the detection of differences between muscle protein extracts:

Solution III

$$
\begin{gathered}
0.05 M \mathrm{KCl}+0.023 M \mathrm{Na}_{2} \mathrm{HPO}_{4} 2 \mathrm{aq}+0.01 M \mathrm{KH}_{2} \mathrm{PO}_{4} \\
\mathrm{p}_{\mathrm{H}}=7 . \mathrm{I} 5 \quad \mu=0.13
\end{gathered}
$$

This solution was then used for all our further experiments, except for those at higher ionic strength.

A phosphate buffer was preferred to a veronal buffer as the larger veronal ion, by combining with the proteins, probably influences the properties of these proteins to a greater extent than the smaller phosphate ions (see PERLMAN AND LONGSWORTH10). $A \mathrm{p}_{\mathrm{H}}$ of 7.15 is a compromise between better separation of $\delta$ and $\varepsilon$ gradients at higher and more details at lower $\mathrm{p}_{\mathrm{H}}$.

The time required to develop the pattern along the whole length of the basis line now proved to be $c$. I3,000 seconds. So two experiments could be performed on one day.

As a matter of fact those parts of the diagrams which can still be recorded after $c$. 3o, ooo sec show still more details (see Fig. 7). But then it is impossible to run two experiments on one day.

Fig. $6 \mathrm{~b}$ shows the diagrams obtained in this solution with an 8 days old extract of white muscle. They can be compared with the diagrams of Fig. 5a-h (of extracts Io-I8 days old) in order to compare Solution III with Solutions $A$ to $H$.

That the differences between the diagrams of Fig. $6 \mathrm{~b}$ and of Fig. 5a-h must indeed be attributed to the influence of the salt solution on the separation of the protein components is demonstrated by Figs. 8 and 9. Fig. 8 shows the diagrams of the same extract with which the diagrams of Fig. $6 \mathrm{~b}$ were obtained after dialyzing the extract for a second time, now against Solution E. By comparison with Fig. $5 \mathrm{e}$ it is apparent that the protein composition of our extracts was materially the same in both cases. As the diagrams of Fig. $5 \mathrm{e}$ and 8 were developed at I $_{75}$ Volts it remained to be demonstrated that the improved separation of the components in the diagrams of Fig. $6 \mathrm{~b}$ is not due to the higher voltage used. This is shown by the diagrams of Fig. 9 developed at I70 Volts, which are materially the same as the diagrams of Fig. $6 \mathrm{~b}$, developed at 225 Volts.

\section{Aging of the extract}

Fig. 6a shows the diagrams obtained with a one day old extract. Another portion of the same extract, now 8 days old, gave us the diagrams reproduced in Fig. $6 \mathrm{~b}$. The References $p .86$. 
TABLE

NUMERICAL EVALUATION OF THE DIAGRAMS OBTAINED IN THE

The area of the Gauss curves fitted in the diagrams (Fig. 5g) expressed in percentages

\begin{tabular}{|c|c|c|c|c|c|c|c|c|}
\hline \multirow{2}{*}{$\begin{array}{c}\text { Rabbit } \\
\text { No. }\end{array}$} & \multirow{2}{*}{$\begin{array}{l}\text { Exp. } \\
\text { No. }\end{array}$} & \multirow{2}{*}{ Solution } & \multirow{2}{*}{$\begin{array}{c}t \\
(\mathrm{sec})\end{array}$} & & & \multicolumn{3}{|c|}{ Component } \\
\hline & & & & & & 2 & 4 & 5 \\
\hline IV & I79 & $\mathrm{G}$ & 5220 & desc. & $\begin{array}{l}\mathrm{pCt} \\
m\end{array}$ & $\begin{array}{l}4.4 \\
6.8\end{array}$ & $\begin{array}{r}14.2 \\
3.9\end{array}$ & $\begin{array}{r}15.9 \\
3.0\end{array}$ \\
\hline IV & 179 & $\mathrm{G}$ & 5220 & asc. & $\begin{array}{l}\mathrm{pCt} \\
m\end{array}$ & $\begin{array}{l}5.9 \\
7.0\end{array}$ & $\begin{array}{r}15.3 \\
4.7\end{array}$ & $\begin{array}{r}\text { II. } 7 \\
4 . I\end{array}$ \\
\hline
\end{tabular}

TABLE

NUMERICAL EVALUATION OF THE DIAGRAMS

For abbreviations pCt

\begin{tabular}{|c|c|c|c|c|c|c|c|c|}
\hline \multirow{2}{*}{$\begin{array}{c}\text { Rabbit } \\
\text { No. }\end{array}$} & \multirow{2}{*}{$\begin{array}{l}\text { Exp. } \\
\text { No. }\end{array}$} & \multirow{2}{*}{ Solution } & \multirow{2}{*}{$\begin{array}{c}t \\
(\mathrm{sec})\end{array}$} & & & \multicolumn{3}{|c|}{ Component } \\
\hline & & & & & & 2 & 4 & 5 \\
\hline $\begin{array}{l}\mathrm{v} \\
\mathrm{v}\end{array}$ & $\begin{array}{l}\text { I86 } \\
\text { I } 86\end{array}$ & $\begin{array}{l}\text { III } \\
\text { III }\end{array}$ & $\begin{array}{l}\mathrm{I}_{4000} \\
\mathrm{I} 4000\end{array}$ & $\begin{array}{l}\text { desc. } \\
\text { asc. }\end{array}$ & $\begin{array}{l}\mathrm{pCt} \\
m \\
\mathrm{pCt} \\
m\end{array}$ & $\begin{array}{l}4.3 \\
5.8 \\
4.8 \\
6.0\end{array}$ & $\begin{array}{l}7.2 \\
2.7 \\
9.7 \\
3.3\end{array}$ & $\begin{array}{l}9.0 \\
2.3 \\
8.1 \\
2.6\end{array}$ \\
\hline $\begin{array}{l}\mathrm{v} \\
\mathrm{v}\end{array}$ & $\begin{array}{l}192 \\
192\end{array}$ & $\begin{array}{l}\text { III } \\
\text { III }\end{array}$ & $\begin{array}{l}13100 \\
13100\end{array}$ & $\begin{array}{l}\text { desc. } \\
\text { asc. }\end{array}$ & $\begin{array}{l}\mathrm{pCt} \\
m \\
\mathrm{pCt} \\
m\end{array}$ & $\begin{array}{l}4 . \mathrm{I} \\
6.2 \\
4.8 \\
6.5\end{array}$ & $\begin{array}{l}7.3 \\
2.8 \\
9.2 \\
3.4\end{array}$ & $\begin{array}{r}9.9 \\
2.4 \\
12.4 \\
2.6\end{array}$ \\
\hline
\end{tabular}

difference between these two pairs of diagrams must be attributed to the different ages of the two portions of the extract. The difference only appears to be caused by the conversion of component 9 into a less soluble form during aging. As a matter of fact in the course of several days' standing in the refrigerator at $2^{\circ} \mathrm{C}$ the extract becomes slightly more opalescent. A small quantity of protein can then be separated by 5 minutes' centrifuging at $10,000 \times \mathrm{g}$. Our diagrams indicate that this protein precipitate mainly consists of component 9 .

The formation of this precipitate has first been noted by VoN FürTH. WEBER AND STöver ${ }^{11}$ reported the formation of 3-5 $\mathrm{mg}$ of precipitate ("myogen-fibrin") per g of protein present. Diagrams obtained by us indicate that component 9 is also removed from the extract, and then completely and along with part of component 4 , when the extract is dialyzed against distilled water until all the salt has been completely removed (see, however, Dubursson ${ }^{12}$ ). This precipitate has been called globulin-X by WEBER AND MEYER ${ }^{13}$.

$\mathrm{JACOB}^{2}$ could detect changes in his diagrams after an aging of 5 days. However the diminishing of component 9 could already be detected by us between diagrams of extracts resp. one and two days old. This conclusion can only be drawn when the diagrams are compared by visual inspection upon superposed projection, and not on the strength of the figures for the protein percentages and the standard deviations. From this the advantage of the first method can again be seen.

References p. 86. 
II

PYROPHOSPHATE SOLUTION G OF PH $=8.64$ AND $\mu=0.13$

of the total area $(\mathrm{pCt})$ and mobilities of the components $(m)$, in $10^{-5} \mathrm{~cm}^{2} \mathrm{Volt}^{-1} \mathrm{sec}^{-1}$.

\begin{tabular}{|c|c|c|c|c|c|c|c|}
\hline \multicolumn{4}{|c|}{ Component } & \multirow{2}{*}{$\begin{array}{l}\text { Sum of } \\
\text { components }\end{array}$} & \multirow{2}{*}{$\begin{array}{c}\delta \text { or } \varepsilon \\
\text { gradient }\end{array}$} & \multirow{2}{*}{$\begin{array}{l}\text { Tot. area } \\
\left(\mathrm{cm}^{2}\right)\end{array}$} & \multirow{2}{*}{$\begin{array}{l}\text { Age of } \\
\text { extract } \\
\text { (days) }\end{array}$} \\
\hline 6 & 7 & 8 & 9 & & & & \\
\hline & $\begin{array}{r}3 \mathrm{I} . \mathrm{O} \\
2.4\end{array}$ & $\begin{array}{r}\mathrm{I} 3 . \mathrm{O} \\
1.8\end{array}$ & & 78.5 & $\begin{array}{r}5.2 \\
+\quad 0.2\end{array}$ & 72 & I7 \\
\hline $\begin{array}{l}4.4 \\
3.6\end{array}$ & $\begin{array}{r}32.4 \\
3.2\end{array}$ & $\begin{array}{l}8.2 \\
2.8\end{array}$ & $\begin{array}{l}4.7 \\
2.3\end{array}$ & 82.6 & $\begin{array}{r}21.6 \\
0.0\end{array}$ & 73 & 17 \\
\hline
\end{tabular}

III

(FIG. 6) OBTAINED IN SOLUTION III

and $m$ see Table II.

\begin{tabular}{|c|c|c|c|c|c|c|c|}
\hline \multicolumn{4}{|c|}{ Component } & \multirow{2}{*}{$\begin{array}{l}\text { Sum of } \\
\text { components }\end{array}$} & \multirow{2}{*}{$\begin{array}{c}\delta \text { or } \varepsilon \\
\text { gradient }\end{array}$} & \multirow{2}{*}{$\begin{array}{l}\text { Tot. area } \\
\left(\mathrm{cm}^{2}\right)\end{array}$} & \multirow{2}{*}{$\begin{array}{l}\text { Age of } \\
\text { extract } \\
\text { (days) }\end{array}$} \\
\hline 6 & 7 & 8 & 9 & & & & \\
\hline $\begin{array}{l}3.8 \\
I .7 \\
4.2 \\
2 . I\end{array}$ & $\begin{array}{r}22 . \mathrm{I} \\
I .5 \\
20 . \mathrm{I} \\
I .6\end{array}$ & $\begin{array}{r}27.6 \\
I . I \\
27.4 \\
I . I\end{array}$ & $\begin{array}{r}17.2 \\
0.8 \\
15.5 \\
0.5\end{array}$ & $\begin{array}{l}91.2 \\
89.8\end{array}$ & $\begin{array}{l}4.2 \\
0.0 \\
4.9 \\
0.0\end{array}$ & $\begin{array}{r}96 \\
\text { I00 }\end{array}$ & $\begin{array}{l}\text { I } \\
\text { I }\end{array}$ \\
\hline & $\begin{array}{r}19.3 \\
I .5 \\
21.4 \\
I .6\end{array}$ & $\begin{array}{r}27.2 \\
I . I \\
30.1 \\
I . I\end{array}$ & $\begin{array}{r}11.9 \\
0.7 \\
11.7 \\
0.6\end{array}$ & $\begin{array}{l}79.7 \\
89.6\end{array}$ & $\begin{array}{r}2.0 \\
+0.5 \\
8.0 \\
+0.4\end{array}$ & $\begin{array}{l}103 \\
105\end{array}$ & $\begin{array}{l}8 \\
8\end{array}$ \\
\hline
\end{tabular}

By dialyzing for a few hours at room temperature instead of at $2^{\circ} \mathrm{C}$ it was possible to obtain diagrams on the very day on which the extraction of the muscle was performed. These diagrams, however, are of the aged type. Component 9 is very much diminished as compared to the diagrams obtained on the following day after I2 hours' dialyzing at $2^{\circ} \mathrm{C}$.

\section{Salt solution used for extraction}

In our first experiments we used Solution I, as recommended by $\mathrm{JACOB}^{2}$, to extract the proteins soluble in dilute salt solutions. The extraction was followed by dialysis against Solution IV. This solution was also used as the supernatant in electrophoresis. After having adopted Solution III for dialysis and electrophoresis, we decided to use Solution III also for the extraction. From the symmetrical character of the diagrams of Fig. 6a and from the conductivity of the extract when compared with the conductivity of the pure Solution III it can be concluded that 12 hours' dialysis at $2^{\circ} \mathrm{C}$ was now sufficient. This time is much shorter than that needed when different solutions are used for extraction and dialysis + electrophoresis (at least 36 hours).

Therefore Solution III was also used for extraction in all our further experiments, except for those performed at higher ionic strength (see below).

We have further been able to demonstrate that none of the proteins soluble in References p. 86 . 
dilute salt solutions remains occluded in structures consisting of myosin chains and still left intact after extracting the tissue with Solution III. Muscle was treated with the solution of GreEnstein and Edsall (our Solution II), which also dissolves myosin. The very viscous extract was dialyzed against Solution III. The myosin now precipitates together with the proteins always precipitating during the first few hours of dialysis. Upon superposed projection the diagrams of the supernatant proved to be identical to those obtained when Solution III was used both for extraction and dialysis.

To decide whether the quantity of Solution III used for extraction (I ml per $\mathrm{g}$ of muscle) guaranteed complete extraction of all proteins indicated by the diagrams some experiments were carried out in which $2 \mathrm{ml}$ of Solution III was used per $\mathrm{g}$ of muscle. The diagrams obtained in this way (Fig. Ioa) proved upon superposed projection, to be very similar to those obtained with I $\mathrm{ml}$ of Solution IIl per $\mathrm{g}$ of the same muscle. (Fig. Iob). The only difference was that the $2 \mathrm{ml} / \mathrm{g}$ extract contained a little less of component 9 . The contrary would be expected if the I $\mathrm{ml} / \mathrm{g}$ extract should be saturated with this component. As the diagram of the $2 \mathrm{ml} / \mathrm{g}$ extract was made two days later than the I ml/g extract the difference must certainly be ascribed to the aging of the extract, as described above. It was also demonstrated that the protein precipitate formed during the first few hours of dialysis did not occlude our proteins in different relative quantities.

Hence we feel justified to conclude that the diagram obtained with extracts prepared by treating muscle with $\mathrm{I} \mathrm{ml}$ of Solution III per $\mathrm{g}$ indicates the true ratios of the muscle proteins studied by us.

\section{INFLUENCE OF INCREASING THE IONIC STRENGTH OF THE SALT SOLUTION USED FOR EXTRACTION AND DIALYSIS}

In order to demonstrate that the muscle proteins studied represent a sharply defined fraction of the proteins present in muscle it must still be shown that a small increase of the ionic strength $(\mu)$ does not produce any gradual changes in the diagrams.

We extracted muscle with the following solutions:

Solution $K$

$0.05 M \mathrm{KCl}+0.046 M \mathrm{Na}_{2} \mathrm{HPO}_{4} 2 \mathrm{aq}+0.020 M \mathrm{KH}_{2} \mathrm{PO}_{4}$

$\mathrm{p}_{\mathrm{H}}=7.15 \quad \mu=0.2 \mathrm{I}$

Solution $L$

$0.05 M \mathrm{KCl}+0.069 M \mathrm{Na}_{2} \mathrm{HPO}_{4} 2$ aq $+0.030 M \mathrm{KH}_{2} \mathrm{PO}_{4}$

$\mathrm{p}_{\mathrm{H}}=7 . \mathrm{I}_{5} \quad \mu=0.29$

These solutions were also used for dialysis and electrophoresis.

The diagrams obtained (Fig. II) show much less detail than the diagrams obtained with Solution III and do not permit to conclude that other proteins are present in these extracts next to those found in the extracts prepared with Solution III. Table IV shows the data obtained upon analysis of the diagrams of Fig. II and of the diagrams obtained from white muscles of the same rabbit with Solution III.

This leads us to the conclusion that the proteins present in our extracts constitute a sharply defined class, for which the diagrams obtained with Solution III may be considered to be representative. 

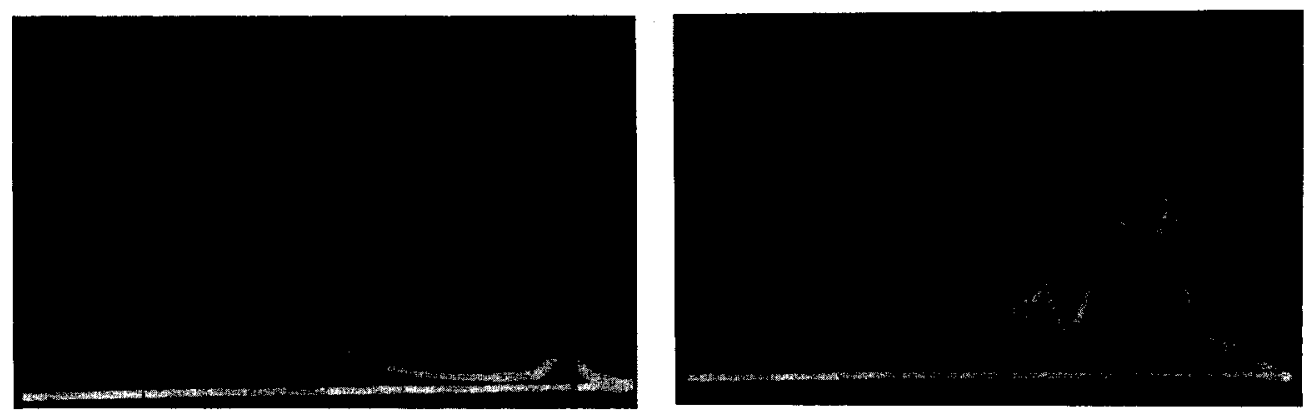

$\overrightarrow{\text { Asc. }}$

a
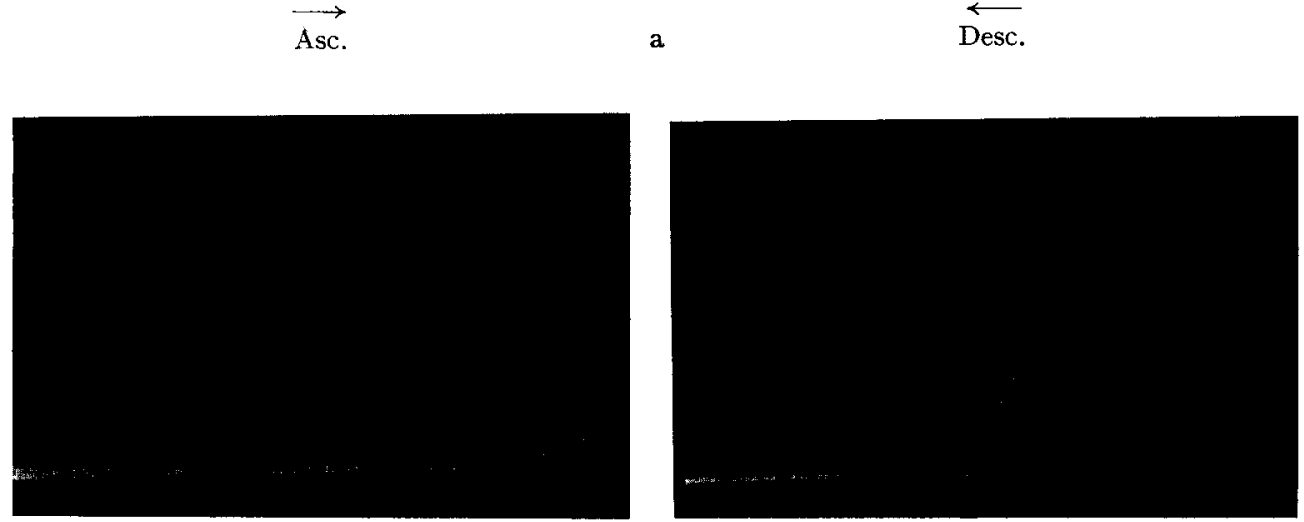

$\longrightarrow$

b

Desc.

Fig. 6. Electrophoresis in Solution III

Rabbit V. Mixed white muscles. Extraction, dialysis and electrophoresis with Solution III. $E=225 \mathrm{~V}, i=0.035 \mathrm{~A}, \Theta=55^{\circ}$ Asc. and desc.

a. Age of extract: I day, $t=14,000 \mathrm{sec}$, Table III, exp. 186 .

b. Age of extract: 8 days, $t=13,000 \mathrm{sec}$, Table III, exp. 192.
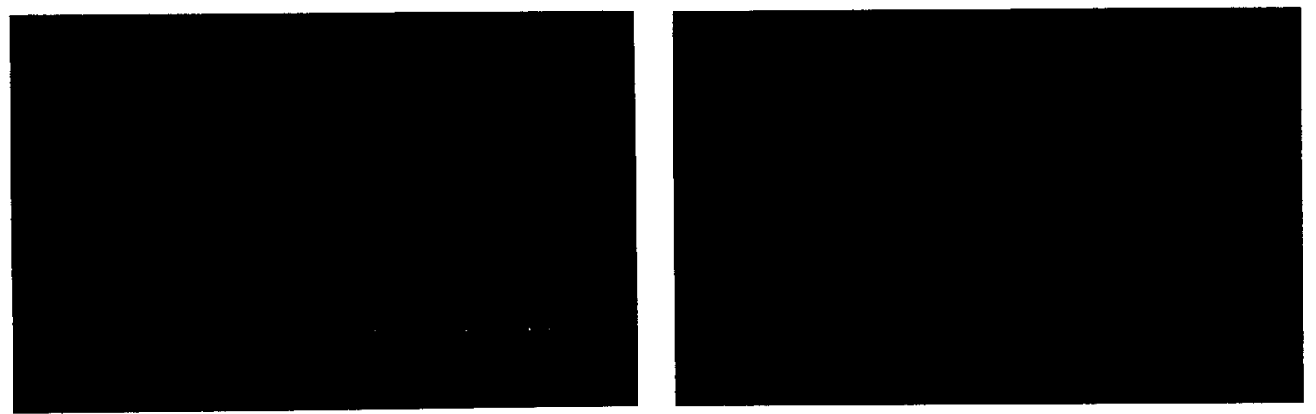

Asc.

Desc.

Fig. 7. Diagrams of ascending and descending boundaries recorded after 30 , ooo sec $\left(\Theta=60^{\circ}\right)$ Same experiment as Fig. 6a.

References p. 86 . 


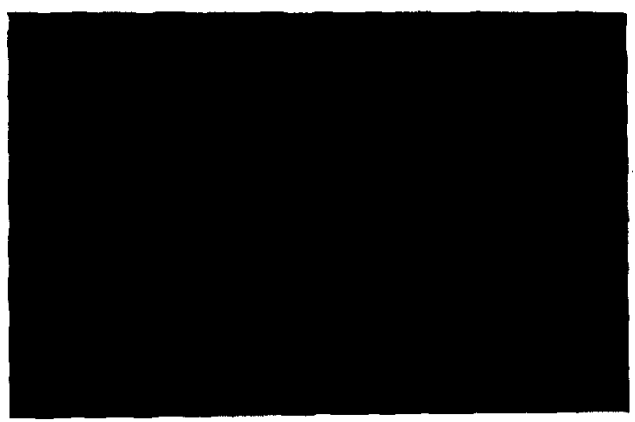

$\leftarrow$

Fig. 8. Diagram obtained after dialyzing the extract used in experiments referred to in Fig. 6 against Solution $\mathrm{E}$

$E=\mathrm{I}_{75} \mathrm{~V}, i=0.040 \mathrm{~A}, t=19.500 \mathrm{sec}, \Theta=55^{\circ}$ Desc. Age of extract: I 2 days.

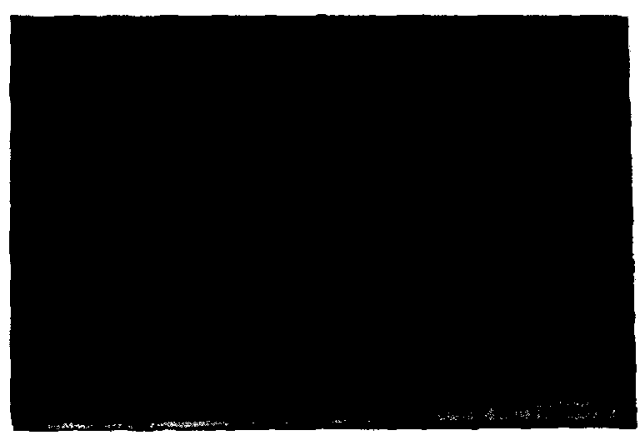

$\rightarrow$ Asc.

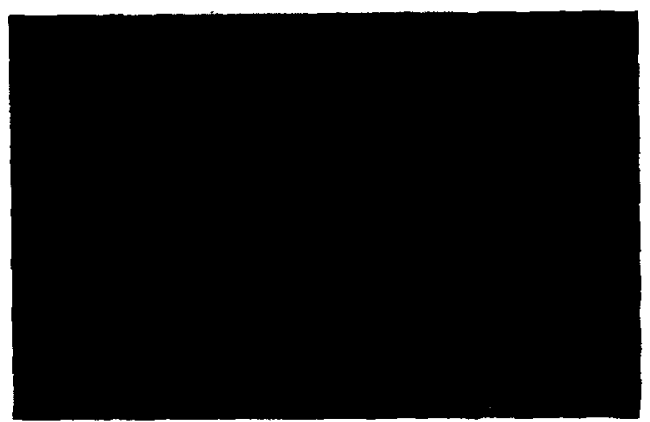

$$
\overrightarrow{\mathrm{Asc}} .
$$

b

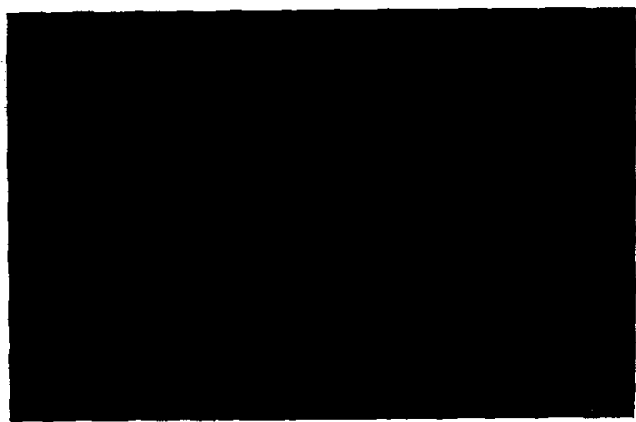

Fig. 9. Electrophoresis in Solution III at $170 \mathrm{~V}$ of extract of which diagrams developed at $225 \mathrm{~V}$ in Solution III are shown in Fig. $6 \mathrm{~b}$

$E=\mathrm{I} 77^{\circ} \mathrm{V}, i=0.025 \mathrm{~A}, t=\mathrm{I} 8$, I $10 \mathrm{sec}, \Theta=55^{\circ}$ Desc. Age of extract: 9 days.

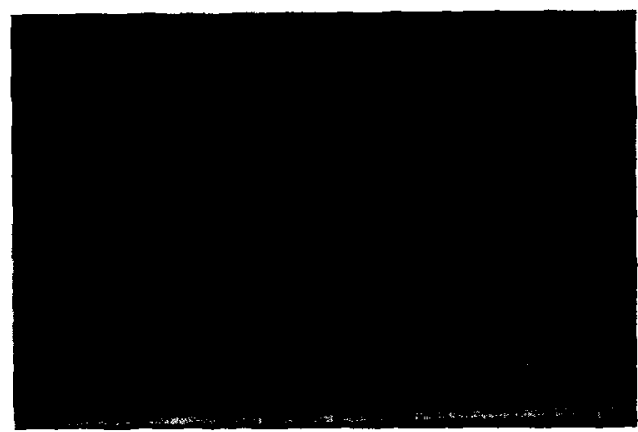

a

$\overleftarrow{\text { Desc. }}$

Fig. IO. Extraction with different quantities of Solution III

Rabbit VI. Mixed white muscles. Dialysis and electrophoresis with Solution III. $E=225 \mathrm{~V}$, $i=0.035 \mathrm{~A}, \Theta=55^{\circ} \quad$ Asc. and desc.

a. $2 \mathrm{ml}$ per $\mathrm{g}$ of muscle. Age of extract: 3 days. $t=12,500 \mathrm{sec}$.

b. I $\mathrm{ml}$ per $\mathrm{g}$ of muscle. Age of extract: I day. $t=\mathrm{I} 3,000 \mathrm{sec}$.

References p. 86. 

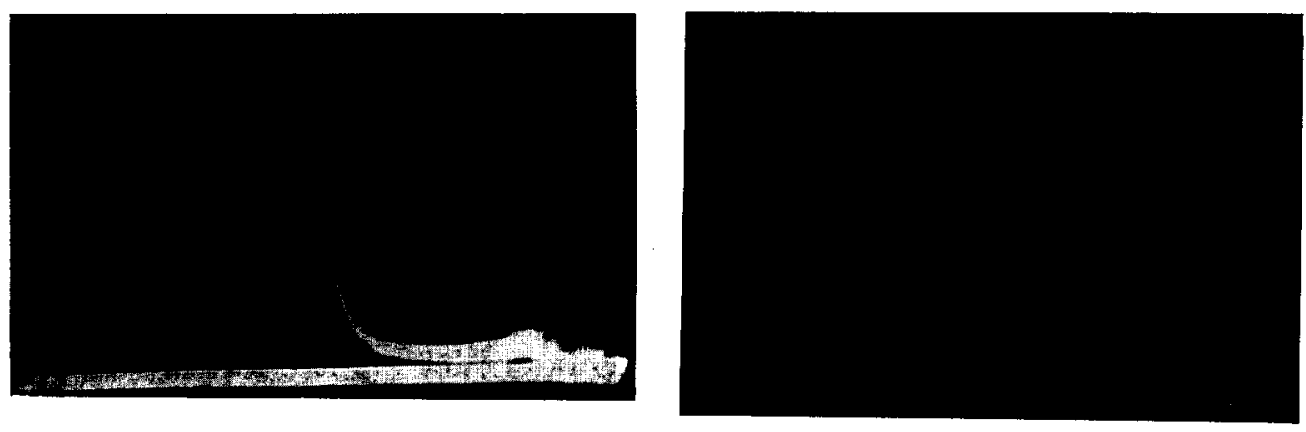

$\overrightarrow{\text { Asc. }}$

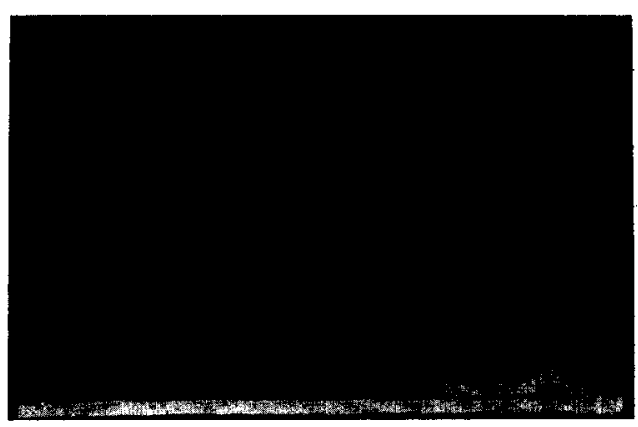

$\longrightarrow$ a

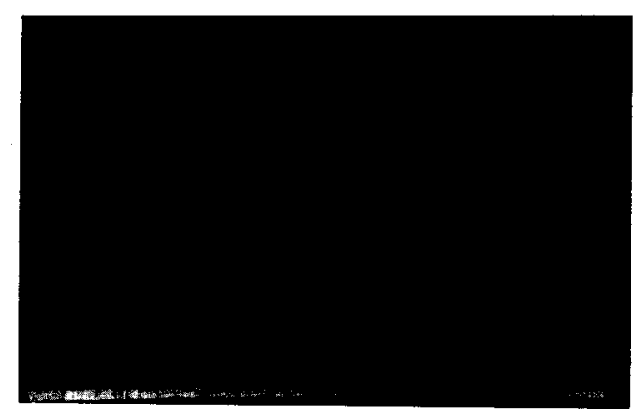

$\longleftarrow$ Desc.

Fig. I I. Influence of increasing the ionic strength of the salt solution used for extraction, dialysis and electrophoresis

Rabbit IX. Mixed white muscles.

a. Solution $\mathrm{K}, \mu=0.2 \mathrm{I}$

$E=200 \mathrm{~V}, i=0.040 \mathrm{~A}, t=\mathrm{I} 4,000 \mathrm{sec}, \Theta=55^{\circ} \quad$ Asc. and desc. Age of extract: 3 days.

Table IV, exp. 272.

b. Solution L, $\mu=0.29$

$E=\mathrm{I} 65 \mathrm{~V}, i=0.040 \mathrm{~A}, t=\mathrm{I} 8,000 \mathrm{sec}, \Theta=55^{\circ} \quad$ Asc. and desc. Age of extract $=2$ days.

Table IV, exp. 27 I.

\section{COMPARISON OF VARIOUS PARTS OF THE WHITE MUSCLE SYSTEM OF ONE RABBIT} AND OF WHITE MUSCLES OF DIFFERENT RABBITS

Various white muscles of one rabbit appear to differ very slightly as regards the proteins studied. This has been shown by making extracts from various samples of randomly chosen white muscles of a rabbit. The differences can only be detected by visual inspection of the superposed projected diagrams. Analysis of the diagrams does not demonstrate significant differences.

As has been described above, no differences can be detected by visual inspection, if the diagrams are made with various samples of one extract or with extracts from various samples of one muscle pulp.

References p. 86 . 
The differences between the white muscles of different rabbits are much more evident than the scarcely observable differences between various samples of white muscles of one rabbit. See Fig. I3 and Table V, compare also Fig. 2, 6 and Io.

\section{COMPARISON OF WHITE AND RED SKELETAL MUSCLE AND SMOOTH MUSCULAR TISSUE OF THE STOMACH OF ONE RABBIT}

Fig. Iob and I2 show the diagrams obtained for white and red striated muscle and for the smooth muscular tissue of the stomach of one rabbit. (The large amount of red pigment present in the extracts prevents the study of heart muscle by the same method). White and red muscle differ only very slightly; the only difference of any importance appears to be the different shape of component 5 .

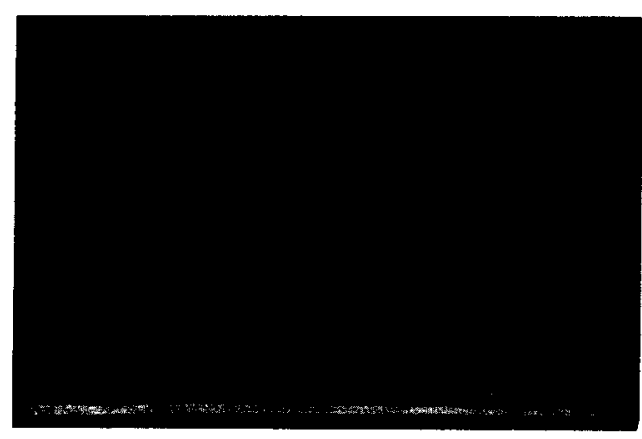

$\overrightarrow{\text { Asc. }}$

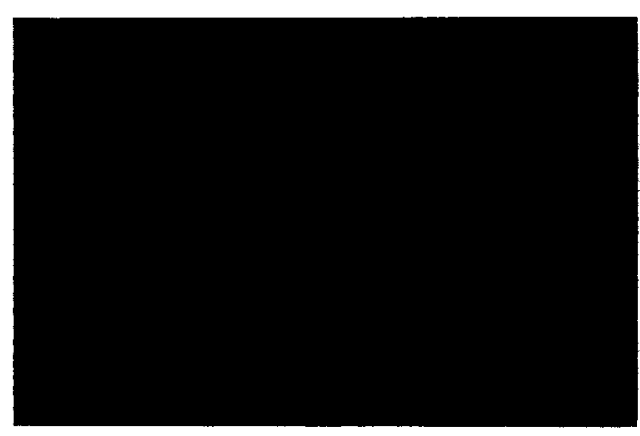

$\overrightarrow{\text { Asc. }}$

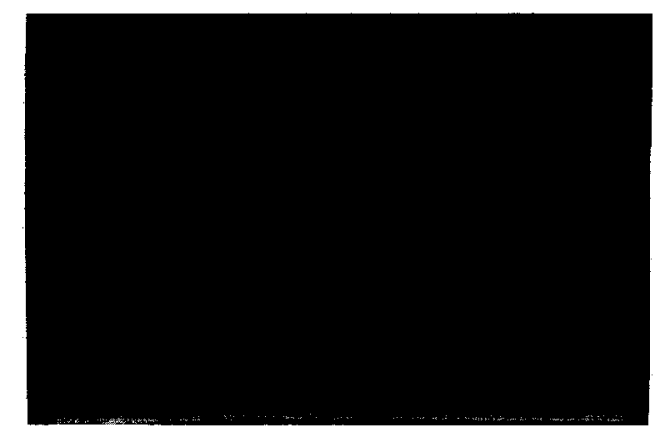

a

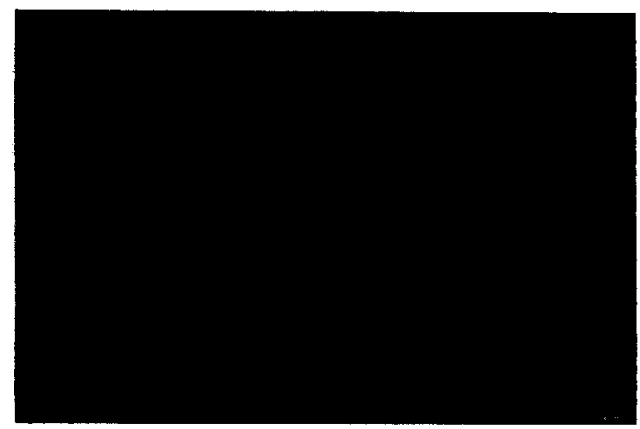

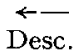

Fig. I2. Comparison of white and red skeletal muscles and smooth muscular tissue of the stomach Rabbit VI. Extraction, dialysis and electrophoresis with Solution III. $E=225 \mathrm{~V}, i=0.035 \mathrm{~A}$, Asc. and desc.

a. Red muscle $\quad t=10,500 \mathrm{sec}, \Theta=55^{\circ}$

b. Stomach muscle $t=6,500$ sec, $\Theta=45^{\circ}$

For white muscle see Fig. Iob.

References p. 86. 
The diagrams obtained with stomach muscle show an entirely different pattern, as is demonstrated by Fig. I2b. It will be obvious that a reasonable analysis by means of Gauss curves of the diagrams as given in this figure is impossible. These patterns are always found for the muscular tissue of rabbit stomach.
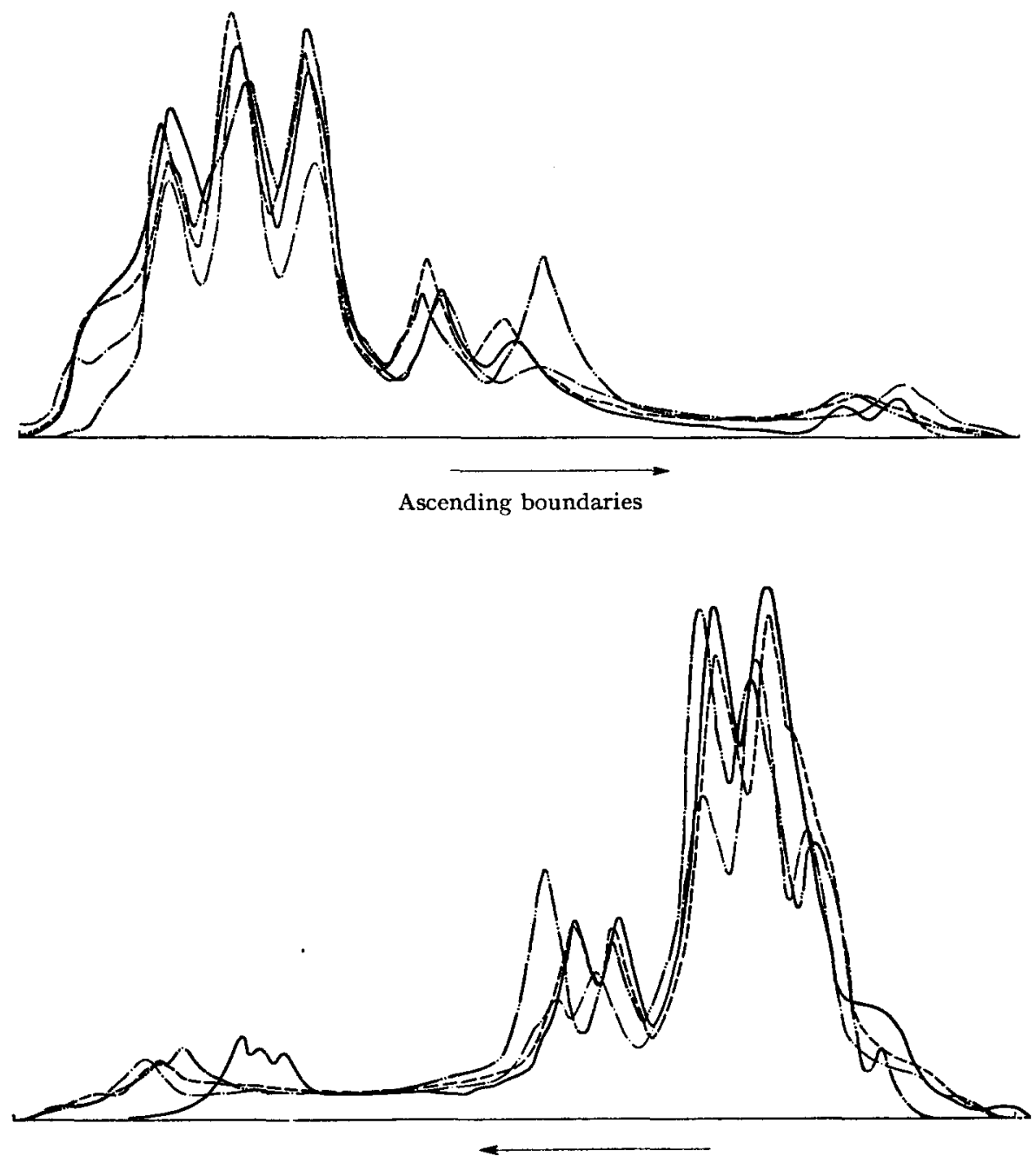

Descending boundaries

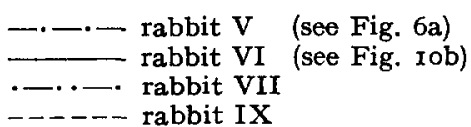

Fig. 13. Superposed projections of mixed white muscles of different rabbits

Extraction, dialysis and electrophoresis with Solution III. $E=$ c. $225 \mathrm{~V}, i=0.035 \mathrm{~A}, t=$ c. I3,000 sec, $\Theta=55^{\circ}$ Asc, and desc.

References p. 86 . 
TABLE

NUMERICAL EVALUATION OF THE DIAGRAMS OBTAINED

For abbreviations pCt

\begin{tabular}{|c|c|c|c|c|c|c|c|c|c|}
\hline \multirow{2}{*}{$\begin{array}{l}\text { Rabbit } \\
\text { No. }\end{array}$} & \multirow{2}{*}{$\begin{array}{l}\text { Exp. } \\
\text { No. }\end{array}$} & \multirow{2}{*}{ Solution } & \multirow{2}{*}{$\begin{array}{c}\text { Ionic } \\
\text { strength }\end{array}$} & \multirow{2}{*}{$\begin{array}{c}t \\
(\mathrm{sec})\end{array}$} & & & \multicolumn{3}{|c|}{ Component } \\
\hline & & & & & & & 2 & 3 & 4 \\
\hline IX & 269 & III & 0.13 & 13000 & desc. & $\underset{m}{\mathrm{pCt}}$ & $\begin{array}{l}4.8 \\
6.3\end{array}$ & & $\begin{array}{l}9.2 \\
2.8\end{array}$ \\
\hline IX & 269 & III & 0.13 & 13000 & asc. & $\begin{array}{l}\mathrm{pCt} \\
m\end{array}$ & $\begin{array}{l}5.7 \\
6.3\end{array}$ & & $\begin{array}{l}9.0 \\
3.3\end{array}$ \\
\hline IX & 272 & $\mathrm{~K}$ & $0.2 \mathrm{I}$ & 14000 & desc. & $\underset{m}{\mathrm{pCt}}$ & $\begin{array}{l}5 \cdot 5 \\
6.0\end{array}$ & $\begin{array}{l}4.8 \\
3.2\end{array}$ & $\begin{array}{r}10.8 \\
2.8\end{array}$ \\
\hline IX & $27^{2}$ & $\mathbf{K}$ & $0.2 \mathrm{I}$ & 14000 & asc. & $\begin{array}{l}\mathrm{pCt} \\
m\end{array}$ & $\begin{array}{l}4.7 \\
5.6\end{array}$ & $\begin{array}{l}4.8 \\
3.3\end{array}$ & $\begin{array}{r}10.7 \\
2.8\end{array}$ \\
\hline IX & $27 \mathrm{I}$ & L & 0.29 & $\mathrm{I} 8000$ & desc. & $\underset{m}{\mathrm{pCt}}$ & $\begin{array}{l}4.6 \\
5.6\end{array}$ & $\begin{array}{l}4.3 \\
3.2\end{array}$ & $\begin{array}{r}14.2 \\
2.7\end{array}$ \\
\hline IX & $27 \mathrm{I}$ & L & 0.29 & 20000 & asc. & $\begin{array}{l}\mathrm{pCt} \\
m\end{array}$ & $\begin{array}{l}5.9 \\
5.4\end{array}$ & $\begin{array}{l}3.7 \\
3.5\end{array}$ & $\begin{array}{r}15.3 \\
2.9\end{array}$ \\
\hline
\end{tabular}

TABLE

NUMERICAL EVALUATIONS OF THE DIAGRAMS OF THE MIXED

a. The area of the Gauss curves fitted in the

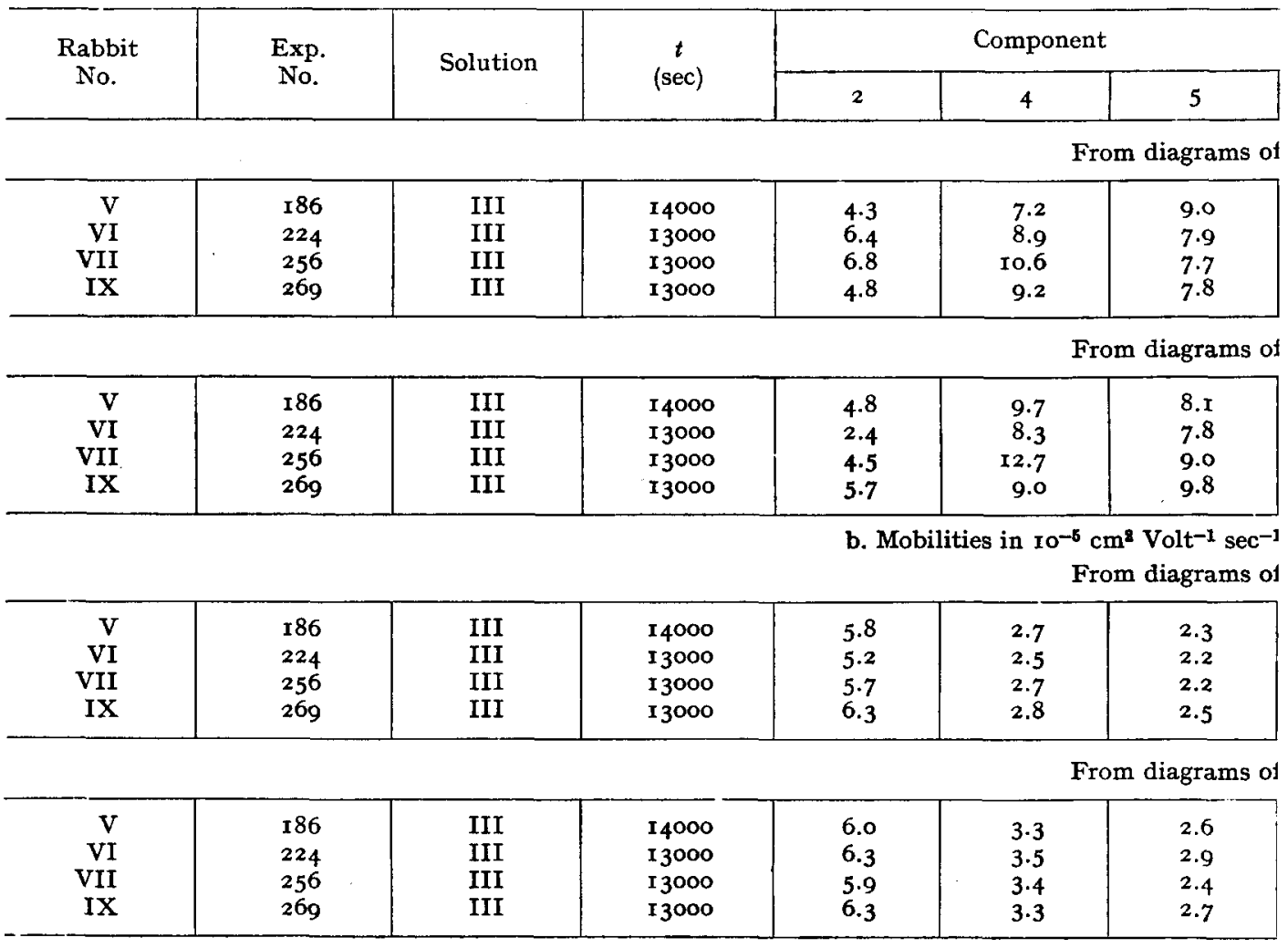

References $p .86$. 
IV

WITH SALT SOLUTION OF HIGHER IONIC STRENGTH

and $m$ see Table II

\begin{tabular}{|c|c|c|c|c|c|c|c|c|c|}
\hline \multicolumn{5}{|c|}{ Component } & \multirow{2}{*}{$\begin{array}{c}\text { Sum of } \\
\text { com- } \\
\text { ponents }\end{array}$} & \multirow{2}{*}{$\begin{array}{c}\delta \text { or } \varepsilon \\
\text { gradient }\end{array}$} & \multirow{2}{*}{$\begin{array}{l}\text { Tot. area } \\
\left(\mathrm{cm}^{2}\right)\end{array}$} & \multirow{2}{*}{$\begin{array}{l}\text { Age of } \\
\text { extraet } \\
\text { (days) }\end{array}$} & \\
\hline 5 & 6 & 7 & 8 & 9 & & & & & \\
\hline 7.8 & 4.0 & 25.4 & 22.2 & 18.4 & 9 r. 8 & 4.5 & II & I & \\
\hline 2.5 & $2 . x$ & $I .6$ & $I .2$ & 0.9 & & 0.0 & & & \\
\hline 9.8 & 2.9 & 24.2 & 27.1 & I6.I & 94.8 & 9.7 & II 7 & I & \\
\hline 2.7 & 2.2 & 1.7 & $I . I$ & 0.5 & & 0.0 & & & \\
\hline 8.0 & & 29.0 & & & 92.I & 5.8 & I I3 & 3 & See \\
\hline 2.4 & & $I .6$ & & & & $+I .4$ & & & Fig. I Ia \\
\hline 8.9 & 3.6 & $3 I .4$ & & & 94.6 & 10.5 & IO9 & 3 & See \\
\hline 2.4 & 2.0 & $I .4$ & & & & $+I .4$ & & & Fig. I Ia \\
\hline 8.8 & & & & & 98.4 & $7 . \mathrm{I}$ & II I & 2 & \\
\hline 2.3 & & & & & & +0.3 & & & Fig. I t b \\
\hline 9.8 & & & & & 9г.9 & I I. 8 & 120 & 2 & See \\
\hline 2.5 & & & & & & +03 & & & Fig. I I b \\
\hline
\end{tabular}

$\mathrm{V}$

WHITE MUSCLES OF DIFFERENT RABBITS (SEE FIG. I3)

tiagrams expressed in percentages of the total area

\begin{tabular}{c|c|c|c|c|c|c|c}
\hline \multicolumn{4}{|c|}{ Component } & $\begin{array}{c}\text { Sum of } \\
\text { components }\end{array}$ & $\begin{array}{c}\delta \text { or } \varepsilon \\
\text { gradient }\end{array}$ & $\begin{array}{c}\text { Tot. area } \\
\left(\mathrm{cm}^{2}\right)\end{array}$ & $\begin{array}{c}\text { Age of } \\
\text { extract } \\
\text { (days) }\end{array}$ \\
\hline 6 & 7 & 8 & 9 & \\
\hline
\end{tabular}

descending boundaries

\begin{tabular}{|c|c|c|c|c|c|c|c|}
\hline 3,8 & 22.1 & 27.6 & 17.2 & 87.4 & 4.2 & 96 & I \\
\hline 6.0 & 24.5 & \multicolumn{2}{|c|}{37.4} & 9I.I & 7.8 & I 6 & $\mathbf{I}$ \\
\hline 2.8 & 22.6 & 27.4 & 14.4 & 92.3 & 2.4 & II9 & 2 \\
\hline 4.0 & 25.4 & 22.2 & 18.4 & 9 г.8 & 4.5 & I I9 & I \\
\hline
\end{tabular}

ascending boundaries

\begin{tabular}{|l|l|l|l|l|l|l|l|l}
\hline 4.2 & 20.1 & 27.4 & I5.5 & 89.8 & 4.9 & roo & I \\
4.6 & 21.8 & 25.6 & 20.4 & 91.5 & 8.3 & I I0 & I \\
2.8 & 25.0 & 27.0 & 13.4 & 94.4 & 3.7 & I I & 2 \\
2.9 & 24.2 & 27.1 & I6.I & 94.8 & 9.7 & I I & I \\
\hline
\end{tabular}

descending boundaries

\begin{tabular}{|c|c|c|c|c|c|}
\hline $\begin{array}{l}\text { I. } 7 \\
\text { I.7 } \\
1.8 \\
2.1\end{array}$ & $\begin{array}{l}1.5 \\
1.3 \\
1.5 \\
1.6\end{array}$ & $\begin{array}{l}\text { I.I } \\
\text { I.I } \\
\text { I. } 2\end{array}$ & $\begin{array}{l}0.8 \\
0.5 \\
0.9\end{array}$ & $\begin{array}{r}0.0 \\
+\quad 0.3 \\
+\quad 0.1 \\
0.0\end{array}$ & $\begin{array}{l}\text { I } \\
\text { I } \\
2 \\
\text { I }\end{array}$ \\
\hline
\end{tabular}

ascending boundaries

\begin{tabular}{|c|c|c|c|c|c|}
\hline $2 . I$ & I. 6 & I.I & 0.5 & 0.0 & I \\
\hline 2.3 & I. 8 & I. 2 & 0.6 & 0.0 & I \\
\hline 1.9 & I. 5 & I.O & 0.2 & 0.0 & 2 \\
\hline 2.2 & I.7 & $\mathbf{I} \cdot \mathbf{I}$ & 0.5 & 0.0 & I \\
\hline
\end{tabular}

References $p .86$. 


\section{DISCUSSION}

The experiments described have shown that visual inspection of superposed projections of diagrams provide a means to detect very small differences between these diagrams. Adopting this procedure no difference could be demonstrated between protein solutions prepared from one batch of muscle, while the differences between various parts of the skeletal muscle system of one rabbit were only very small. The differences between muscles of various rabbits, however, were much more pronounced. Hence samples of one mass of muscle pulp or, if necessary, samples of muscles of one rabbit, but not homologous muscles of various rabbits, should be used if one wants to study the influence of various extraction methods, the influence of the salt solution, etc. on the diagram.

We are not yet able to connect the nine protein components, as indicated by our diagrams, with proteins, e.g. enzymes, isolated or postulated by other investigators.

We have been wondering, whether component 2 might be identical with plasma albumin, as both have the same mobility in Solution III. Though the concentration of component 2 in our extracts is low (ca $5 \%$ ) and the concentration of albumin in the blood plasma of the rabbit is high (ca $75 \%)^{\mathbf{1 4}}$, we do not believe component 2 to be plasma albumin, as there can only be very little blood present in the exsanguinated muscle and interstitial fluids only contain a very small amount of protein.

Our extracts contain the proteins which have been termed Myogen and Globulin-X. Our diagrams show, however, that these names do not refer to two individual proteins, but to mixtures of at least seven and two components respectively.

It is impossible at present to maintain the old definition of myosin, viz. the protein of muscle soluble in $0.5 \mathrm{M} \mathrm{KCl}$ solution at $\mathrm{p}_{\mathrm{H}} 7.5$, (compare $\left.{ }^{15,1,16}\right)$. As a matter of fact our extracts when freshly prepared contain a protein which in the course of time only remains in the dissolved state if the salt concentration is increased to about $0.5 M \mathrm{KCl}$. When the muscle is ground in a mortar with a more dilute salt solution (e.g. Solution III), and sand, a very viscous extract is obtained, from which no protein can be separated by centrifuging even at ro,ooo $\mathrm{g}$. In the course of a few hours' standing at $2^{\circ} \mathrm{C}$, however, a very voluminous protein precipitate is formed, which can easily be spun off at $600 \mathrm{~g}$. The supernatant has then lost the original high viscosity. We believe the sedimented protein, which can be dissolved again in $0.5 \mathrm{M} \mathrm{KCl}$ solution, to be identical with the myosin commonly studied. This is prepared in many cases by a lengthy procedure in which it is alternatively dissolved in $0.5 \mathrm{M} \mathrm{KCl}$ solution and precipitated by dilution. It seems possible that this dilution of the $0.5 \mathrm{M} \mathrm{KCl}$ solution causes the same alterations resulting in a decreased solubility of the myosin as occur in our extracts. In conclusion we believe the myosin present in muscle to be soluble in dilute salt solution (of an ionic strength of $c$. O.I5), but to undergo an intramolecular rearrangement in these solutions resulting in the formation of a less soluble form. As a matter of fact we obtained identical protein solutions, whether we carried out the extraction by $0.5 \mathrm{~mol} \mathrm{KCl}$ or by Solution III, in both cases followed by dialysis against Solution III.

The case of component 9 is complicated. I) It precipitates during aging of the extracts. 2) It appears to be a component of the globulin-X (see p. I4). 3) The diagrams of the protein solutions, prepared by extracting the lipids from the highly viscous fresh muscle extracts according to $\mathrm{BLIX}^{17}$ and extracting the dry powder obtained in this way with Solution III, indicate the presence of a large amount of a protein, whose gradient is situated at the same place as component 9 . This extract is rather viscous. 
In the course of a few days protein precipitates and can be removed by centrifuging. The supernatant of low viscosity provides a diagram, which shows the gradient of component 9 of the usual magnitude. The behaviour of this component suggests identity with STRAUB's actin ${ }^{18}$.

\section{ACKNOWLEDGEMENT}

The author wishes to express his gratitude to Prof. Westenbrink for valuable aid and criticism received during the course of the investigation and the elaboration of the results, and to Drs. E. Wiedemann AND J. A. Niemeijer for assistance with the technique of the electrophoretic measurements.

\section{SUMMARY}

The quantitative aspects of the electrophoresis of the muscle proteins of the myogen-globulin- $\mathrm{X}$ group, soluble in dilute salt solutions, were studied.

The most sensitive method of detecting differences between diagrams appears to be visual inspection of superposed projections (magnification ro-fold to a base length of $34.5 \mathrm{~cm}$ ).

With respect to symmetry of the diagrams, the number of details detectable in the diagrams and the time required for full development along the basis of the diagrams, a KCl-phosphate solution of $\mathrm{pH} 7.15$ and ionic strength 0.13 appeared to have most adequate properties.

As the diagrams change upon aging of the extracts this solution was also used for extraction in order to shorten the time required for dialysis. With I 2 hours' dialysis at $2^{\circ} \mathrm{C}$ and 13,000 seconds of electrophoresis diagrams could thus be obtained within 24 hours after the animal was bled in narcosis.

I $\mathrm{ml}$ of this solution per $\mathrm{g}$ of muscle was shown to provide complete extraction of the group of proteins studied.

Skeletal muscle of the rabbit gave after 13,000 seconds of electrophoresis patterns in which nine protein components could be detected, eight of these occurring in concentrations sufficiently high to permit their numerical evalution from the diagrams. The protein components do not gradually change in number and amounts upon increasing the ionic strength of the solution used for extraction, dialysis and electrophoresis. Thus the proteins studied constitute a sharply defined class, for which the diagrams obtained may be considered to be representative.

While diagrams of extracts of various samples of one batch of muscle pulp appeared to be quite identical upon visual inspection of the superposed projections, small differences could be detected between extracts of randomly chosen different parts of the white muscle system of one rabbit. More pronounced differences appeared to exist between white muscles of different rabbits. The differences between white and red muscles of one rabbit are only small, while the smooth muscular tissue of the stomach gives a completely different pattern.

\section{RESUME}

Nous avons étudié les aspects quantitatifs de l'électrophorèse des protéines musculaires du groupe myogène-globuline- $\mathrm{X}$, solubles dans les solutions salines diluées.

Nous avons trouvé que la méthode la plus sensible pour déceler des différences entre diagrammes est l'inspection, à l'œil, de projections superposées (agrandissement: 1o fois, jusqu'à une longueur de base de $34.5 \mathrm{~cm}$ ).

Pour l'obtention de diagrammes symétriques, pour déceler le plus grand nombre possible de détails dans les diagrammes et pour atteindre un développement complet des diagrammes le long de la ligne de base en un temps aussi court que possible, une solution de $\mathrm{KCl}$-phosphate de PH 7.15 et de force ionique o.r3 est la plus adéquate.

Puisque les diagrammes changent lorsque les extraits vieillissent, nous avons employé cette même solution pour l'extraction, afin d'abréger le temps nécessaire pour la dialyse. Par une dialyse de 12 heures à $2^{\circ}$ et une électrophorèse de 13,000 secondes nous avons obtenu ainsi des diagrammes en moins de 24 heures après la saignée de l'animal sous narcose.

Nous avons montré que I ml de cette solution par gramme de muscle permet d'extraire complètement le groupe de protéines étudiées.

Des muscles du squelette de Lapin ont donné, après $\times 3,000$ secondes d'électrophorèse, des images permettant de déceler neuf fractions de protéines. Huit d'entre elles apparaissent en des concentrations suffisamment élevées pour être évaluées d'après les diagrammes. Les fractions de protéines ne

References p. 86. 
changent pas graduellement en nombre et en quantité lorsque la force ionique employée pour l'extraction, la dialyse et l'électrophorèse augmente. Les protéines étudiées constituent donc une classe bien définie pour laquelle les diagrammes obtenus peuvent être considérés comme représentatifs.

Tandis que différents échantillons d'une même pâte de muscle se revèlent tout-à-fait identiques lors de l'inspection à l'œil des projections superposées, de petites différences ont pu être distinguées dans les extraits de différentes parties choisies au hasard du système musculaire blanc d'un même lapin. Nous avons montré que des différences plus prononcées existent entre les muscles blancs de lapins différents. Les differences entre les muscles blancs et rouges du même lapin ne sont que petites, tandis que le tissu musculaire lisse de l'estomac donne une image complètement différente.

\section{ZUSAMMENFASSUNG}

Die quantitative Seite der Elektrophorese der Muskeleiweisskörper der Myogen-Globulin-XGruppe, die in verdünnten Salzlösungen löslich sind, wurde studiert.

Die empfindlichste Methode, um Unterschiede zwischen Diagrammen zu entdecken, ist, wie sich herausstellte, die visuelle Betrachtung superponierter Projektionen (zehnfache Vergrösserung zur Basislänge $34.5 \mathrm{~cm}$ ).

Zur Erzielung symmetrischer Diagramme und einer maximalen Anzahl merkbarer Einzelheiten und $\mathrm{um}$ in der kleinstmöglichen Zeit volle Entwicklung entlang der Basislinie der Diagramme zu erreichen, erwies eine $\mathrm{KCl}-\mathrm{Phosphatlösung} \mathrm{von} \mathrm{PH}_{7.1}$ und einer Ionenstärke von $0 . \mathrm{I}_{3}$ sich als die geeignetste.

Da die Diagramme sich bei Altern der Extrakte ändern, wurde diese Lösung auch für die Extraktion benutzt, um die für die Dialyse nötige Zeit zu verkürzen. Bei zwölfstündiger Dialyse bei $+2^{\circ} \mathrm{C}$ und I3,0oo Sekunden Elektrophoresedauer konnten auf diese Weise Diagramme innerhalb 24 Stunden, nachdem das Tier unter Narkose leergeblutet wurde, erhalten werden.

I $\mathrm{ml}$ dieser Lösung per $\mathrm{g}$ Muskel genügt, wie gezeigt wurde, zur vollständigen Extraktion der untersuchten Eiweissgruppe.

Kaninchenskelettmuskel ergab nach 13,000 Sekunden Elektrophorese Bilder, in denen neun Eiweisskomponenten entdeckt werden konnten. Davon kommen acht in Konzentrationen vor, die hoch genug sind, um sie aus den Diagrammen auszurechnen. Die Eiweisskomponenten ändern sich nicht allmählich, was ihre Anzahl und Menge betrifft, wenn die Ionenstärke der Lösung, die zur Extraktion, Dialyse und Elektrophorese benutzt wird, gesteigert wird. Die untersuchten Eiweisskörper bilden also eine gut definierte Klasse, für die die erhaltenen Diagramme als repräsentativ betrachtet werden können.

Während die Diagramme verschiedener Proben aus einer Menge Muskelbrei sich bei visueller Betrachtung der superponierten Projektionen als vollständig identisch erwiesen, konnten zwischen Extrakten von willkürlich gewählten Teilen des weissen Muskelsystems desselben Kaninchens kleine Unterschiede entdeckt werden. Ausgesprochenere Unterschiede bestehen, wie sich herausstellte, zwischen den weissen Muskeln verschiedener Kaninchen. Die Unterschiede zwischen den weissen und den roten Muskeln desselben Kaninchens sind nur gering, aber die glatte Muskulatur des Magens ergibt ein vollkommen abweichendes Bild.

\section{REFERENCES}

1 H. H. WeBER, Biochim. Biophys. Acta, 4 (I950) I 2.

2 J. JACOB, Biochem. J., 4I (I947) 83.

${ }^{3}$ E. C. Bate Smith, $J$. Physiol., i Io (1949) 47.

4 J. P. Greenstein and J. T. Edsall, J. Biol. Chem., i 33 (1940) 397.

5 C. Alvarez Tostado, $J$. Biol. Chem., 135 (1940) 799.

6 T. Svedberg and K. O. Pedersen, The Ultracentrifuge, p. 296, London, I940.

7 E. Wiedemann, Helv. Chim. Acta, 30 (1947) 892.

A. Tiselius and E. A. Kabat, J. exptl Med., 69 (I939) I I9.

${ }^{2}$ L. G. Longsworth, Chem. Rev., 30 (1942) 323.

10 C. E. Perlman and L. G. Longsworth, $f$. Am. Chem. Soc., 70 (1948) 2719.

11 H. H. Weber and R. Stöver, Biochem. Z., 259 (I933) 269.

12 M. Dubuisson, Bioch. Méd., IX, (1948) I, see p. 26.

$13 \mathrm{H}$. H. Weber AND K. MEyer, Biochem. Z, 266 (I933) I 37.

14 D. H. MOORE, J. Biol. Chem., I6I (1945) 2 I.

15 H. H. Weber, Ergebn. Physiol., 36 (1934) rog.

16 M. Dubursson, Experientia, 3 (I947) 372.

17 G. Blix, J. biol. Chem., I37 (I94I) 495.

18 P. B. Straub, Studies Inst. Med. Chem. Univ. Szeged, 2 (5946) 3; 3 (5943) 23. 